\title{
Size distribution, mixing state and source apportionment of black carbon aerosol in London during wintertime
}

\author{
D. Liu ${ }^{1}$, J. D. Allan ${ }^{1,6}$, D. E. Young ${ }^{1}$, H. Coe ${ }^{1}$, D. Beddows ${ }^{4}$, Z. L. Fleming ${ }^{2}$, M. J. Flynn ${ }^{1}$, M. W. Gallagher ${ }^{1}$,

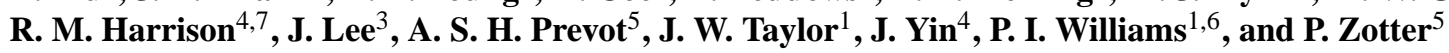 \\ ${ }^{1}$ School of Earth, Atmospheric and Environmental Science, University of Manchester, Manchester, UK \\ ${ }^{2}$ Department of Chemistry \& National Centre for Atmospheric Science, University of Leicester, Leicester, UK \\ ${ }^{3}$ Department of Chemistry \& National Centre for Atmospheric Science, University of York, York, UK \\ ${ }^{4}$ Division of Environmental Health and Risk Management, School of Geography, Earth and Environmental \\ Sciences, University of Birmingham, Birmingham, UK \\ ${ }^{5}$ Laboratory of Atmospheric Chemistry, Paul Scherrer Institute (PSI), 5232 Villigen PSI, Switzerland \\ ${ }^{6}$ National Centre for Atmospheric Science, University of Manchester, Manchester, UK \\ ${ }^{7}$ Department of Environmental Sciences/Center of Excellence in Environmental Studies, King Abdulaziz University, \\ P.O. Box 80203, Jeddah, 21589, Saudi Arabia
}

Correspondence to: D. Liu (dantong.liu@manchester.ac.uk)

Received: 30 May 2014 - Published in Atmos. Chem. Phys. Discuss.: 20 June 2014

Revised: 19 August 2014 - Accepted: 29 August 2014 - Published: 22 September 2014

\begin{abstract}
Black carbon aerosols (BC) at a London urban site were characterised in both winter- and summertime 2012 during the Clean Air for London (ClearfLo) project. Positive matrix factorisation (PMF) factors of organic aerosol mass spectra measured by a high-resolution aerosol mass spectrometer (HR-AMS) showed traffic-dominant sources in summer but in winter the influence of additional non-traffic sources became more important, mainly from solid fuel sources (SF). Measurements using a single particle soot photometer (SP2, DMT), showed the traffic-dominant BC exhibited an almost uniform $\mathrm{BC}$ core size $\left(D_{\mathrm{c}}\right)$ distribution with very thin coating thickness throughout the detectable range of $D_{\mathrm{c}}$. However, the size distribution of $D_{\mathrm{c}}$ (project average mass median $D_{\mathrm{c}}=149 \pm 22 \mathrm{~nm}$ in winter, and $120 \pm 6 \mathrm{~nm}$ in summer) and BC coating thickness varied significantly in winter. A novel methodology was developed to attribute the $\mathrm{BC}$ number concentrations and mass abundances from traffic $\left(\mathrm{BC}_{\mathrm{tr}}\right)$ and from $\mathrm{SF}\left(\mathrm{BC}_{\mathrm{sf}}\right)$, by using a 2-D histogram of the particle optical properties as a function of $\mathrm{BC}$ core size, as measured by the SP2. The $\mathrm{BC}_{\mathrm{tr}}$ and $\mathrm{BC}_{\mathrm{sf}}$ showed distinctly different $D_{\mathrm{c}}$ distributions and coating thicknesses, with $\mathrm{BC}_{\mathrm{sf}}$ displaying larger $D_{\mathrm{c}}$ and larger coating thickness compared to $\mathrm{BC}_{\mathrm{tr}}$. $\mathrm{BC}$ particles from different sources were also apportioned by applying a multiple linear regression between the
\end{abstract}

total BC mass and each AMS-PMF factor (BC-AMS-PMF method), and also attributed by applying the absorption spectral dependence of carbonaceous aerosols to 7-wavelength Aethalometer measurements (Aethalometer method).

Air masses that originated from westerly (W), southeasterly (SE), and easterly (E) sectors showed $\mathrm{BC}_{\mathrm{sf}}$ fractions that ranged from low to high, and whose mass median $D_{\mathrm{c}}$ values were $137 \pm 10 \mathrm{~nm}, 143 \pm 11 \mathrm{~nm}$ and $169 \pm 29 \mathrm{~nm}$, respectively. The corresponding bulk relative coating thickness of BC (coated particle size/BC core $-D_{\mathrm{p}} / D_{\mathrm{c}}$ ) for these same sectors was $1.28 \pm 0.07,1.45 \pm 0.16$ and $1.65 \pm 0.19$. For $\mathrm{W}$, $\mathrm{SE}$ and $\mathrm{E}$ air masses, the number fraction of $\mathrm{BC}_{\text {sf }}$ ranged from $6 \pm 2 \%$ to $11 \pm 5 \%$ to $18 \pm 10 \%$, respectively, but importantly the larger $\mathrm{BC}$ core sizes lead to an increased fraction of $\mathrm{BC}_{\mathrm{sf}}$ in terms of mass than number (for W, SE and $\mathrm{E}$ air masses, the $\mathrm{BC}_{\mathrm{sf}}$ mass fractions ranged from $16 \pm 6 \%$, $24 \pm 10 \%$ and $39 \pm 14 \%$, respectively). An increased fraction of non-BC particles (particles that did not contain a BC core) was also observed when SF sources were more significant. The BC mass attribution by the SP2 method agreed well with the BC-AMS-PMF multiple linear regression method (BC-AMS-PMF : SP2 ratio $=1.05, r^{2}=0.80$ ) over the entire experimental period. Good agreement was found between $\mathrm{BC}_{\mathrm{sf}}$ attributed with the Aethalometer model and the 
SP2. However, the assumed absorption Ångström exponent $\left(\alpha_{\mathrm{wb}}\right)$ had to be changed according to the different air mass sectors to yield the best comparison with the SP2. This could be due to influences of fuel type or burn phase.

\section{Introduction}

Increased anthropogenic emissions into the atmosphere have led to severe air quality issues, especially for urbanised megacities with high population densities. Understanding, identifying and characterising the sources of air pollution and their effects on surrounding areas, is important for validating environmental pollution control policies, as well as for climate radiative forcing assessment at local and global scales (Lawrence et al., 2007). Aerosol emissions have been widely recognised as having adverse effects on the environment, the hydrological cycle, support ecosystems and the human health of the exposed population (Gurjar et al., 2010). The Greater London urban area is the most populated conurbation in Europe and covers an area of $1.738 \mathrm{~km}^{2}$. The Clean Air for London (ClearfLo) campaign was conducted during 2012 with two intensive observation periods (IOPs), one in winter and one in summer, to investigate the range of pollutant sources to which the London population are exposed to and to provide comprehensive aerosol and trace gas composition data for tackling air quality issues.

Environmental regulation has targeted emissions from fossil fuel combustion by transport, power plants and a variety of industrial activities. However, residential solid fuel burning for space heating purposes (SF, such as coal or wood burning) has received less attention in terms of enforcement of regulations in recent years. There are a growing number of studies (especially in the rest of Europe) that highlight the importance of residential burning and their contribution to particulate matter (PM) loadings, especially during wintertime when space heating activities are high and boundary layer mixing is suppressed. These studies examined a variety of environments including rural sites, alpine valleys, as well as urban sites across mid-western Europe (Crippa et al., 2014), including the following: Switzerland (Szidat et al., 2007; Sandradewi et al., 2008; Herich et al., 2011), UK (Allan et al., 2010; Liu et al., 2011; Harrison et al., 2012a), France (Favez et al., 2010; Healy et al., 2012; Laborde et al., 2013), Austria (Caseiro et al., 2009), Norway (Yttri et al., 2009) and Ireland (Dall'Osto et al., 2013). Organic mass fractions in sub-micron aerosols contributed by the SF sources reported in these studies ranged from 15 to $50 \%$, consistently highlighting the importance of wood burning as a source contribution during winter (Herich et al., 2014).

These studies aimed to evaluate SF source influences through a variety of receptor-based source apportionment methodologies. A widely accepted method is to use a sin- gle SF tracer, such as soluble potassium or levoglucosan (Puxbaum et al., 2007), identified by higher organic carbon fraction compared to elemental carbon (OC/EC) or by radiocarbon measurements, which are used to separate modern non-fossil ${ }^{14} \mathrm{C}$ and fossil particulate carbon (Szidat et al., 2007). Site receptor models are widely utilised for source apportionment (Viana et al., 2008), and linearly assign several identified source factor profiles to the measured total mass concentration, speciated chemical composition and some other undetermined additive properties in a time series. Depending on whether the source profiles are assumed a priori, the receptor models can be mainly classified as relying on the methodologies of chemical mass balance (CMB) and factor analysis (FA). The former requires prior knowledge of source profiles, whereas the latter determines the number and characteristics of the sources a posteriori. CMB has been commonly applied to offline analysis (e.g. Chow et al., 2007), while FA has been applied to Aerodyne aerosol mass spectrometer (AMS) organic mass spectral data to attribute sources (Zhang et al., 2005; Lanz et al., 2010). Positive matrix factorisation (PMF, Paatero, 1997) analysis is often applied to AMS organic matrices to evaluate sources under a variety of environments, e.g. using the PMF evaluation toolkit (PET), introduced by Ulbrich et al. (2009). In addition, the multi-linear engine (ME-2) (Canonaco et al., 2013) can serve as a compromise between the CMB and FA (Lanz et al., 2008). Other methodologies include source attribution based on the spectral dependence of light absorption of brown carbon using multi-wavelength Aethalometer instruments (Sandradewi et al., 2008). This has become popular, as the measurement is suited to routine monitoring applications.

The methodologies above have mostly focused on the organic carbon content of SF sources; however, the information of source attribution for black carbon aerosols (BC) is sparse, due to the difficulties in measuring the refractory component in the aerosols. Given BC is the principal source of particulate light absorption in the atmosphere (Bond et al., 2013) with adverse effects on human health (e.g. Jansen et al., 2005; Mordukhovich et al., 2009), it is of great importance to understand $\mathrm{BC}$ sources and how its properties are dictated by those sources. The study presented here uses data from the North Kensington site in London during the ClearfLo experiment campaign conducted in 2012. The physical properties of $\mathrm{BC}$ were characterised in detail by a single particle soot photometer (SP2, DMT). A source apportionment methodology has been developed based on the measured $\mathrm{BC}$ size distribution and mixing state. It is the first time that $\mathrm{BC}$ sources are quantitatively attributed directly from their physical properties in this way and this apportionment is used to evaluate the estimates from the other methodologies. This study provides detailed insights on source-specific BC properties and these properties have a significant impact on both air quality and climate radiative forcing. 


\section{Experimental site and data analysis}

This study reports continuous measurements from the Clean Air for London (ClearfLo) experimental campaign which is described by Bohnenstengel et al. (2013) and (http://www. clearflo.ac.uk) for two intensive observation periods (IOPs) during 2012. Both IOPs lasted for four weeks and were conducted in winter (11 Janurary to 8 February) and summer (18 July to 22 August); the latter IOP occurring during the period of the London 2012 Olympic Games. The experimental site was located in the grounds of a school in North Kensington, which is representative of a typical London urban background environment and also the site of a DEFRA Automated Urban and Rural Network (AURN) monitoring site (http://uk-air.defra.gov.uk/networks/). The London urban environment in winter is significantly influenced by solid fuel burning sources, such as wood burning for residential heating (Allan et al., 2010). In contrast, vehicle emissions form the majority of the $\mathrm{BC}$ source in summer.

The scientific objective of this study was to investigate how the combined sources during the winter season influenced the BC physical properties, and to compare and contrast the different methods used to quantitatively apportion the BC from different sources and provide a critical assessment of their accuracy and reliability.

\subsection{The single particle soot photometer}

The physical properties of individual refractory $\mathrm{BC}$ particles (rBC, Petzold et al., 2013) were characterised using a single particle soot photometer (SP2) manufactured by DMT Inc. The instrument operation and data interpretation procedures of the specific Manchester SP2 instrument have been described elsewhere (Liu et al., 2010; McMeeking et al., 2010). Briefly, the SP2 uses an intra-cavity Nd:YAG laser at $1064 \mathrm{~nm}$ to determine the optical size of a single particle by light scattering and, if material within the particle absorbs at the laser wavelength, the refractory mass of the particle is quantified by detection of the laser induced incandescence radiation. In the atmosphere the main light-absorbing component at this wavelength is BC. The SP2 incandescence signal was used to obtain single particle $\mathrm{rBC}$ mass after calibration using Aquadag ${ }^{\circledR}$ sample black carbon particle standards (Aqueous Deflocculated Acheson Graphite, manufactured by Acheson Inc., USA). It has however been shown that BC particle standards generated from Aquadag ${ }^{\circledR}$ do not represent ambient $\mathrm{BC}$ and a further correction of 0.75 is required (Moteki and Kondo 2010; Laborde et al., 2012b; Baumgardner et al., 2012). The measured $\mathrm{rBC}$ mass is converted to a mass equivalent diameter $\left(\rho=1.8 \mathrm{~g} \mathrm{~cm}^{-3}\right.$ for atmospheric BC (Bond and Bergstrom, 2006)), which is termed the BC core diameter $\left(D_{\mathrm{c}}\right)$, which is the diameter of a sphere containing the same mass of $\mathrm{rBC}$ as measured in the particle. Any measured particle with a detectable incandescence signal is referred to as a $\mathrm{BC}$ particle, whereas a particle which only exhibits a scattering signal is termed a non-BC particle. The total $\mathrm{rBC}$ mass loading is reported as the sum of all detected single particle $\mathrm{rBC}$ masses. Because a certain amount of $\mathrm{rBC}$ mass exists at core sizes too small to be detected, or too large hereby saturating the detector, these missing masses are predicted based on the extrapolation of a log-normal fit on the $D_{\mathrm{c}}$ mass distribution. In this study, the extrapolated mass ranged from 1 to $8 \%$ depending on the $D_{\mathrm{c}}$ distribution. All of the concentrations reported are at STP volumes (273.15 K, $1013.25 \mathrm{mbar})$.

The scattering signal of a BC particle will be distorted during its transit through the laser beam because of the mass loss of a $\mathrm{BC}$ particle by laser heating, thus the leading edge scattering signal before the onset of volatilisation is extrapolated to reconstruct the scattering signal of a $\mathrm{BC}$-containing particle (Gao et al., 2007). The technical details for the methodology of leading edge only (LEO) fitting as used in this study can be found in the Appendix B. The optical diameter of a BC particle or the coated $\mathrm{BC}$ size $\left(D_{\mathrm{p}}\right)$ is derived by inputting the LEO fitted scattering signal and $\mathrm{BC}$ core size into Mie calculations, and using a core refractive index $(m)=2.26-1.26 i$ (Moteki et al., 2010) and a coating refractive index $m=1.5+0 i$ (Sect. 3.4). The relative or absolute coating thickness of a $\mathrm{BC}$ particle is calculated as $D_{\mathrm{p}} / D_{\mathrm{c}}$ and $\left(D_{\mathrm{p}}-D_{\mathrm{c}}\right) / 2$, respectively. The optical size of a non-BC particle is again calculated using Mie theory using $m=1.5+0 i$, thus the optical sizes of coated $\mathrm{BC}$ and non-BC are directly comparable using the analysis here. Given the coating thickness for individual particles is $D_{\mathrm{c}}$ size dependent, a bulk coating thickness is evaluated as the cubed root of the total volume of the $\mathrm{BC}$ particles divided by the total volume of the $\mathrm{BC}$ cores, as expressed as Eq. (1):

$$
\frac{D_{\mathrm{p}}}{D_{\mathrm{c}}}=\left(\frac{\sum_{i} D_{\mathrm{p}, i}^{3}}{\sum_{i} D_{\mathrm{c}, i}^{3}}\right)^{\frac{1}{3}},
$$

where $D_{\mathrm{p}}$ and $D_{\mathrm{c}}$ are the coated $\mathrm{BC}$ diameter and $\mathrm{BC}$ core diameters, respectively; $i$ denotes the $i$ th single $\mathrm{BC}$ particle. The volume weighted bulk $D_{\mathrm{p}} / D_{\mathrm{c}}$ is considered to be a representative diagnostic for the overall mixing state of the entire population of $\mathrm{BC}$ particles.

\subsection{The HR-ToF-AMS and PMF analysis}

The chemical composition of non-refractory $\mathrm{PM}_{1}$ species were measured by the Aerodyne high-resolution time-offlight aerosol mass spectrometer (HR-ToF-AMS, hereafter AMS), which operated in the standard configuration at North Kensington (NK) site, taking both MS and PToF data. Further details are presented in Young et al. (2014) but a brief description relevant to this work is given here. A detailed description of the instrument can be found elsewhere (DeCarlo et al., 2006; Canagaratna et al., 2007). As the AMS sampled in an alternating sequence with other black carbon and 
aerosol volatility measurements, $5 \mathrm{~m}$ averaged ambient samples in "V mode" were only obtained every $30 \mathrm{~min}$. A time and composition dependent collection efficiency (CE) was applied to the data based on the algorithm by Middlebrook et al. (2012) and was validated by comparing the volume concentration with that of the DMPS measurements. The AMS was calibrated using $350 \mathrm{~nm}$ mono-disperse ammonium nitrate particles.

Positive matrix factorisation (PMF) (Paatero, 1997) was performed on the organic data matrix from the "V-mode" data, permitting analysis of peaks according to elemental composition (Sun et al., 2011). While the "W-mode" data could in theory provide a more detailed analysis, too low a fraction of peaks were consistently fit by PIKA (due to the lower signal-to-noise) to permit a meaningful PMF analysis. A front end for using the related ME-2 algorithm (Lanz et al., 2008; Paatero, 1999) is currently available (Canonaco et al., 2013), which in some circumstances can produce more accurate data. However, the benefits of this approach are most significant when applied to unit mass resolution (UMR) data (from the Q-AMS, C-TOF-AMS and ACSM), where key peaks (such as $\mathrm{C}_{3} \mathrm{H}_{7}^{+}$and $\mathrm{C}_{2} \mathrm{OH}_{3}^{+}$) cannot be explicitly separated and therefore contribute to rotational ambiguity under normal PMF analysis. As this is not an issue with the HRTOF-AMS data presented here, it was decided that it would be most appropriate to use PMF, so the results would not be influenced by a priori assumptions regarding the aerosol's behaviour.

The data were preprocessed in the recommended method of practice as described by Ulbrich et al. (2009). Isotopes were not included in the organic matrix and nitrogencontaining peaks were not deemed to have been successfully retrieved using PIKA. Five factors were identified: oxygenated OA (OOA), cooking OA (COA), hydrocarbon-like OA (HOA) and two solid fuel OA (SFOA 1 and SFOA 2 ), which had the appearance of "split" factors. While the 4-factor solution (which contained only one SFOA factor) seemed to be valid, the 5-factor solution gave improvements to diagnostics (e.g. Q) and correlations with ancillary data (e.g. $\mathrm{NO}_{\mathrm{x}}, \mathrm{BC}$ and $\mathrm{CO}$ ), so it was deemed that the 5-factor solution with the split SFOA factors was the most appropriate. The two SFOA factors had distinctly different amounts of hydrocarbon and oxygen-containing peaks in their mass spectra and could be linked to the ratio of levoglucosan to potassium (Young et al., 2014). It is possible that these two factors represent changes in composition with burn phase, although fuel type cannot be ruled out explicitly. However, it should be noted that Yin et al. (2014) found no relationship between this split and the relative amounts of coal and wood burning. The 6-factor solution was discarded due to its significant dependency on initialisation seed (unlike the solutions with 5 or fewer factors) and as well as the production of a factor that did not appear physically meaningful.

\subsection{The Aethalometer}

A 7-wavelength Aethalometer (MAGEE Scientific, model AE31) was used to derive the mass concentration of light absorbing black carbon particles. In this instrument aerosol particles are collected onto a quartz fibre filter and the resulting light attenuation at $\lambda=370,470,520,590,660$, 880 and $950 \mathrm{~nm}$ is measured. The measured data was corrected for multiple scattering of the light beam within the unloaded filter matrix ( $C$ value) and for the "shadowing effect" ( $f$ value) caused by the already deposited particles which may "shadow" the freshly collected ones so that the new particles are not exposed to the same intensity of light, and do not make the same contribution to the attenuation per unit mass. The approach proposed by Weingartner et al. (2003) using an $f$ value of 1.2 and a $C$ value of 3.095 was used to correct the data. The $C$ value was calculated comparing the uncorrected Aethalometer data with a Thermo Scientific Multi-Angle Absorption Photometer (MAAP) using only data with attenuation values smaller than 10 (Collaud Coen et al., 2010), where no shadowing effect is expected.

The absorption Ångström exponent, $\alpha$, is then calculated according to

$\alpha=\ln \left(b_{\mathrm{abs}, \lambda 1} / b_{\mathrm{abs}, \lambda 2}\right) / \ln \left(\lambda_{2} / \lambda_{1}\right)$,

where absorption, $b_{\mathrm{abs}}$, in the IR at $950 \mathrm{~nm}$ is assumed to be representative for $\mathrm{BC}$ (or elemental carbon), while $470 \mathrm{~nm}$ in the UV indicates the presence of aromatic organic absorbing compounds. The absorption Ångström exponent was calculated here using the absorption measured at wavelengths $\lambda_{1}=470$ and $\lambda_{2}=950 \mathrm{~nm}$ (e.g. Sandradewi et al, 2008). This calculation was repeated at wavelengths $\lambda=370$ and $880 \mathrm{~nm}$ for the purpose of an examination of the two- $\lambda$ Aethalometer measurement which is routinely applied to UK monitoring networks. The $\alpha_{470-950 \mathrm{~nm}}$ was found to agree well with that calculated using the usual $\alpha_{370-880 \mathrm{~nm}}$ to within $\pm 5 \%$.

The $\mathrm{BC}$ mass in this study is reported as the refractory $\mathrm{BC}$ (rBC, Petzold et al., 2013) mass measured by the SP2 instrument, but not the Aethalometer derived $\mathrm{BC}$ mass, i.e. from directly measured absorption coefficient $\left(b_{\mathrm{abs}}\right.$, in $\left.\mathrm{Mm}^{-1}\right)$ to $\mathrm{BC}$ mass (in $\mu \mathrm{g} \mathrm{m}^{-3}$ ) by assuming a mass absorption cross section (MAC, in $\mathrm{m}^{2} \mathrm{~g}^{-1}$ ). Only $b_{\mathrm{abs}}$ from Aethalometer measurement is used, given the discussion of MAC value that should be used is beyond the scope of this paper.

\subsection{The potassium ion and levoglucosan measurements}

A small portion of the Digitel filter samples was extracted with $10 \mathrm{~mL}$ de-ionised water by undergoing $40 \mathrm{~min}$ mechanical agitation to ensure thorough removal of the water-soluble aerosol. The resulting solutions were filtered and analysed for ion potassium using a DIONEX ICS-2000 ion chromatography system coupled with a gradient pump, which generates one eluent from two different solutions, de-ionised 
water and concentrated potassium hydroxide solution. The sample concentrations were calibrated with a series of mixed standards of known concentration (0.01-10 ppm).

A method similar to that in Yin et al. (2010) and Wagener et al. (2012) has been applied but modified for the detection of levoglucosan. In brief, one quarter of the Digitel quartz fibre filter sample was spiked with an internal standard (IS), methyl-beta-D-xylopyranoside (from Sigma-Aldrich Ltd) and extracted with DCM and methanol $(2: 1)$ under mild sonication at room temperature. The combined extract was filtered/dried and concentrated down to nearly dryness and derivatized by addition of N,O-bis(trimethylsilyl)trifluoroacetamide plus $1 \%$ trimethylchlorosilane (BSTFA $+1 \%$ TMCS) and pyridine under $70^{\circ} \mathrm{C}$ for $1 \mathrm{~h}$, and finally cooled in a desiccator. The quantification was based on the IS and a six-point authentic standard calibration curve, with selected ion monitoring (SIM) mode on an Agilent GC-MS instrument. The ions monitored were 204 and 217 for the IS and 204, 217 and 333 for levoglucosan.

\subsection{The gas measurements}

CO measurements were provided with an Aerolaser AL 5002 UV fluorescence instrument which was calibrated using a 200ppb CO standard provided by Air Products and certified to NPL standards. $\mathrm{NO}$ and $\mathrm{NO}_{2}$ data were provided by an Air Quality Design custom built high-sensitivity Chemiluminescence analyser with a Blue Light $\mathrm{NO}_{2}$ converter. The NO instrument was calibrated using a 5 pm NO in nitrogen standard (supplied by BOC) - diluted to $20 \mathrm{ppb}$ using scrubbed zero air (BOC BTCA 178). The $\mathrm{NO}_{2}$ calibration was provided by gas phase titration of the NO standard with $\mathrm{O}_{3}$. $\mathrm{NO}_{\mathrm{y}}$ was also measured using a TEI 42i TL NO analyser with a Molybdenum converter.

\subsection{Meteorology and dispersion modelling}

In order to identify the origin of air masses and estimate transit times over possible source regions, the UK Met Office Numerical Atmospheric-Dispersion Modelling Environment (NAME) dispersion model (Jones et al., 2007) was run using Unified Model (UM) reanalysis meteorological data to generate hourly surface source footprints that describe the origin and pathways of air arriving at the site after 1, 2 or 3 days of transport in a similar manner to Liu et al. (2013). The "1day footprint", defined as the location where air was found within $100 \mathrm{~m}$ of the surface and hence directly influenced by local sources, was chosen to represent the urban environment representative of this study and its immediate local/regional sources rather than the long-range transport influences that would be characterised by over $24 \mathrm{~h}$. Air masses were categorised according to the main regions within the domain of passage (i.e. over the Benelux area, northern France, Atlantic, North Sea, etc.) for the 1-day footprints (Fig. 1a) ac- cording to the technique described in Fleming et al. (2012). The contributions, based on the accumulated time the air mass had spent during the 1-day journey to the station, from each region were calculated as fractions of all the regions for each 3-hourly period. The air masses arriving at the London site can have a variety of influences and this method highlights the periods that are influenced by several regions or just one region in particular. The time periods where the air mass fraction was greater than the 40th percentile of that region's average air mass fraction were deemed to be strongly influenced by that region (Liu et al., 2013), but there were times when there were two or even three strongly influenced regions as shown in Fig. $2 \mathrm{f}$.

Air masses were classified into broader sectors (Fig. 2f): westerly air masses (W) - a combination of air types with footprints from the Atlantic, Ireland and Wales, when the air mass was largely influenced by the relatively cleaner Atlantic ocean sector; easterly air masses (E) - air that has passed over the North Sea and Benelux area; southeasterly air masses (SE) - represents air masses transported over northern France, the English Channel and the southeastern UK. The typical footprints of W, E, and SE air masses are shown in Fig. 1b. As Fig. 2f shows, clear shifts in air masses occurred at midday on the 18 January and the afternoon of 28 January when winds shifted from the SE to $\mathrm{W}$ and then back to E. The E and SE air mass assignments overlapped for the first few days between 15 and 17 January, due to more complex meteorological conditions which resulted in air masses arriving from a variety of different sectors and which were not uniquely classifiable. The $\mathrm{W}$ air mass, which brought warmer Atlantic air, generally corresponded with higher ambient temperatures $\left(8.0 \pm 2.7^{\circ} \mathrm{C}\right)$, whereas the $\mathrm{E}$ air mass, originating from continental Europe, led to colder temperatures $\left(1.8 \pm 2.1^{\circ} \mathrm{C}\right)$, less cloud cover and thus allowed stronger nocturnal inversions to develop.

\section{Results}

\subsection{Overview}

Consistent with the view that westerly air masses will bring relatively cleaner air from the Atlantic sector, whereas easterly air masses will have spent significant time over continental Europe, particularly Benelux and northern France, aerosol loadings were lower in $\mathrm{W}$ air masses, while enhanced mass loadings were observed for all aerosol components when air came from the east (Table 1). This highlights the clear regional influences on these pollutants at the London urban site, consistent with the synoptic influences of pollutants reported, e.g. in Manchester, UK (Martin et al., 2011) and in Harwell (Charron et al., 2013). Harrison et al. (2012b) also showed an increased $\mathrm{PM}_{2.5}$ in the UK when easterly wind associated with air masses from the European mainland. The site was also heavily influenced by local sources. In 


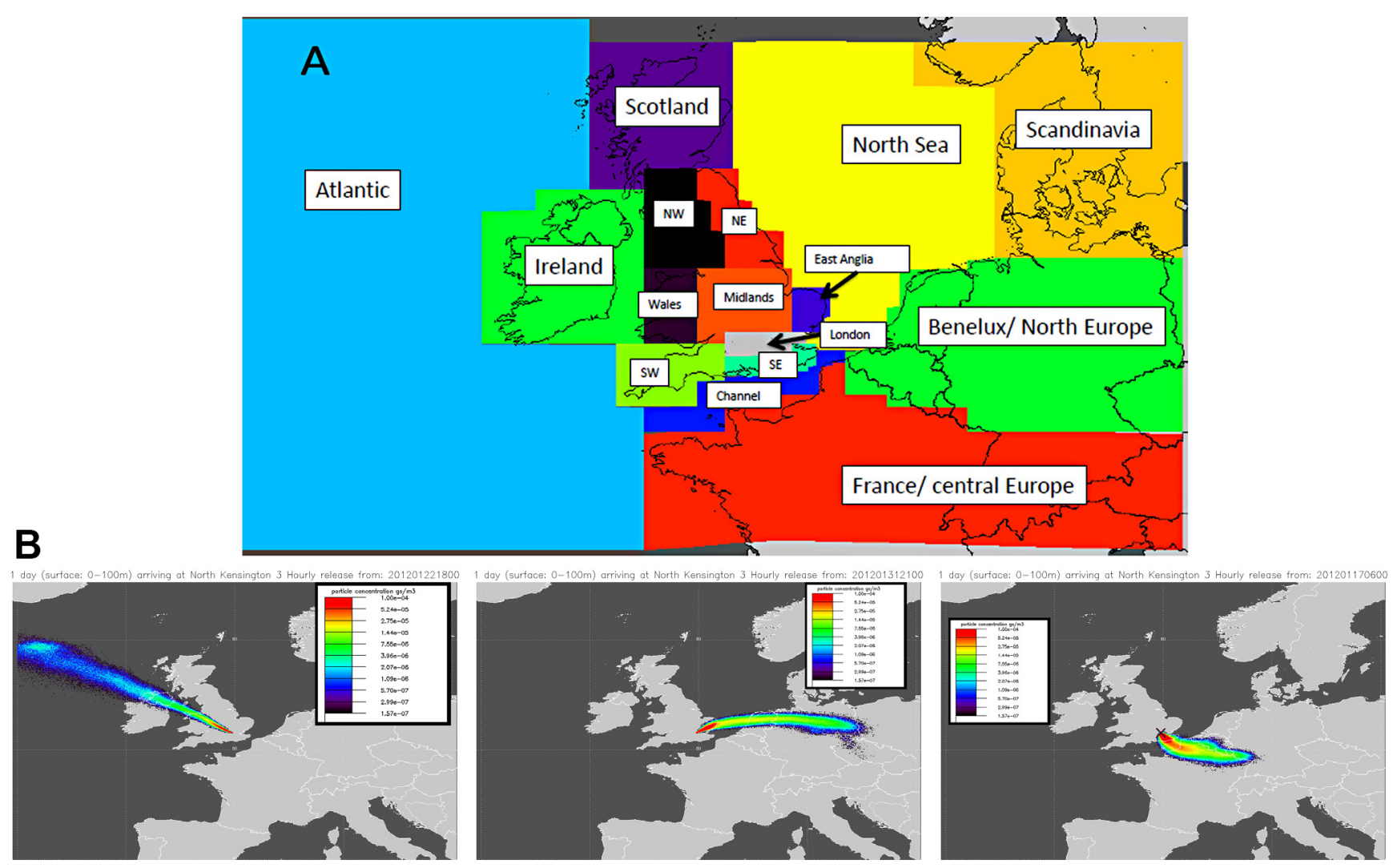

Figure 1. (a) The designated regional influences within the domain of passage for 1-day footprints in the NAME model. (b) Typical footprints for each broadly classified air mass category, the image is coloured by the particle density, with the cross marking the location of receptor.

Table 1. A summary of aerosol/trace gas properties recorded during the different air mass categories, mean $\pm \sigma$ (standard deviation) and with median values in brackets: BC-related properties; AMS aerosol nitrate, sulfate, total organic sub-micron mass, $\mathrm{NO}_{\mathrm{x}}(\mathrm{ppb}), \mathrm{CO}(\mathrm{ppb})$ and ambient temperature properties.

\begin{tabular}{|c|c|c|c|c|c|c|c|}
\hline \multicolumn{8}{|c|}{ BC-related properties } \\
\hline & $\begin{array}{c}\text { BC mass } \\
\text { loading } \\
\left(\mu \mathrm{g} \mathrm{m}^{-3}\right)\end{array}$ & $\begin{array}{c}\text { BC core } \\
\text { diameter } \\
(\mathrm{nm})\end{array}$ & $\begin{array}{l}\text { BC coating } \\
\text { thickness } \\
-D_{\mathrm{p}} / D_{\mathrm{c}}\end{array}$ & $\begin{array}{l}\mathrm{BC} \text { mass } \\
\text { fraction }\end{array}$ & $\begin{array}{c}\text { Absorption } \\
\text { Ångström } \\
\text { Exponent }\end{array}$ & $\begin{array}{l}\mathrm{BC} \text { mass fraction } \\
\text { from } \mathrm{SF} \\
-\mathrm{BC}_{\mathrm{sf}} / \text { Total } \mathrm{BC}\end{array}$ & $\begin{array}{c}\mathrm{BC} \text { number } \\
\text { fraction from } \mathrm{SF} \\
-\mathrm{BC}_{\mathrm{sf}} / \text { Total } \mathrm{BC}\end{array}$ \\
\hline Westerly & $0.90 \pm 0.84(0.67)$ & $137 \pm 10(134)$ & $1.28 \pm 0.07(1.27)$ & $0.17 \pm 0.08(0.15)$ & $1.18 \pm 0.12(1.18)$ & $0.16 \pm 0.06(0.15)$ & $0.06 \pm 0.02(0.06)$ \\
\hline Easterly & $1.13 \pm 0.61(1.08)$ & $169 \pm 29(159)$ & $1.65 \pm 0.19(1.63)$ & $0.06 \pm 0.02(0.05)$ & $1.25 \pm 0.11(1.26)$ & $0.39 \pm 0.14(0.36)$ & $0.18 \pm 0.10(0.15)$ \\
\hline Southeasterly & $1.74 \pm 1.35(1.25)$ & $143 \pm 11(143)$ & $1.45 \pm 0.16(1.43)$ & $0.09 \pm 0.08(0.07)$ & $1.30 \pm 0.15(1.28)$ & $0.24 \pm 0.10(0.22)$ & $0.11 \pm 0.05(0.10)$ \\
\hline \multirow[t]{2}{*}{ Overall } & $1.30 \pm 1.11(0.98)$ & $149 \pm 22(144)$ & $1.45 \pm .020(1.42)$ & $0.11 \pm 0.08(0.08)$ & $1.25 \pm 0.14(1.24)$ & $0.26 \pm 0.13(0.23)$ & $0.12 \pm 0.08(0.10)$ \\
\hline & Nitrate $\left(\mu \mathrm{g} \mathrm{m}^{-3}\right)$ & Sulfate $\left(\mu \mathrm{g} \mathrm{m}^{-3}\right)$ & $\begin{array}{l}\text { Other properties } \\
\text { Organic }\left(\mu \mathrm{g} \mathrm{m}^{-3}\right)\end{array}$ & $\mathrm{NO}_{\mathrm{x}}(\mathrm{ppbv})$ & $\mathrm{CO}$ (ppbv) & Temperature $\left({ }^{\circ} \mathrm{C}\right)$ & \\
\hline Westerly & $1.03 \pm 1.51(0.33)$ & $0.33 \pm 0.32(0.21)$ & $1.65 \pm 1.49(1.14)$ & $30.8 \pm 25.0(24.0)$ & $230 \pm 90(202)$ & $8.0 \pm 2.7(8.4)$ & \\
\hline Easterly & $6.64 \pm 5.26(6.19)$ & $2.18 \pm 1.28(1.89)$ & $4.61 \pm 2.67(3.82)$ & $33.7 \pm 17.3(30.1)$ & $290 \pm 79(284)$ & $1.8 \pm 2.1(2.0)$ & \\
\hline Southeasterly & $6.07 \pm 5.08(4.49)$ & $1.42 \pm 1.05(1.15)$ & $6.47 \pm 4.85(5.63)$ & $67.6 \pm 60.5(47.2)$ & $381 \pm 157(357)$ & $5.0 \pm 2.7(4.7)$ & \\
\hline Overall & $4.61 \pm 4.88(2.62)$ & $1.24 \pm 1.13(0.97)$ & $4.42 \pm 4.10(3.04)$ & $47.2 \pm 46.6(33.0)$ & $308 \pm 138(279)$ & $4.9 \pm 3.7(4.4)$ & \\
\hline
\end{tabular}

particular possibly due to higher ambient temperature during westerly air masses $\left(8.0 \pm 2.7^{\circ} \mathrm{C}\right)$, residential heating activities including from solid fuel burning were reduced and so local emissions were generally lower compared to when easterly air masses prevailed. The lower ambient temperatures during easterly air masses $\left(1.8 \pm 2.1^{\circ} \mathrm{C}\right)$ also lead to reduced boundary layer depth, further increasing the concentrations of local pollutants. The BC-related properties for these periods will be discussed in more detail in Sect. 3.3.

\subsection{BC source attribution by Aethalometer}

$\mathrm{BC}$ mass was attributed between traffic $\left(\mathrm{BC}_{\mathrm{tr}}\right)$ and wood burning sources $\left(\mathrm{BC}_{\mathrm{wb}}\right)$ by linear application of the constant absorption Ångström exponent $(\alpha)$ for pure traffic $\left(\alpha_{\mathrm{tr}}\right)$ and 


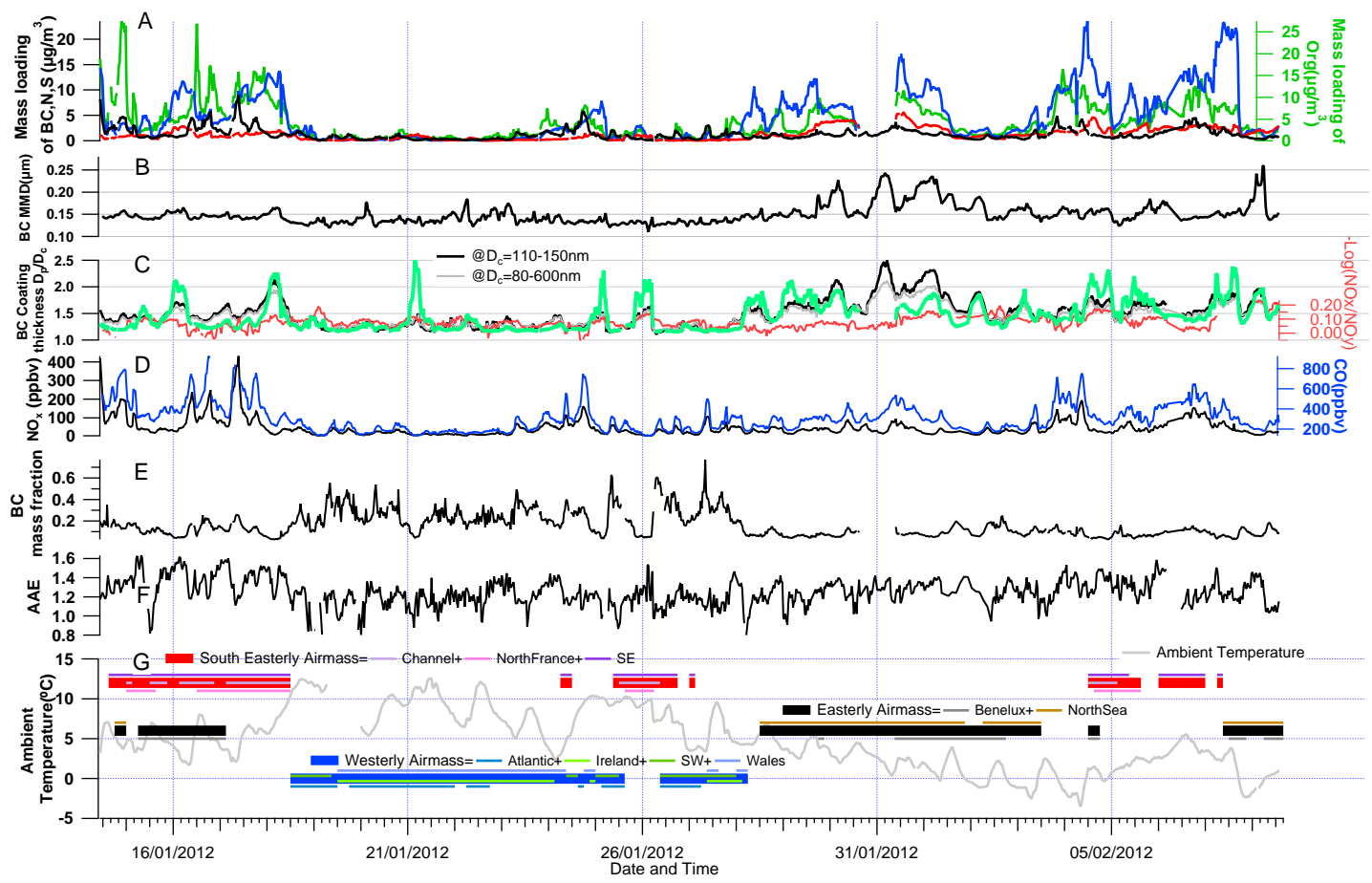

Figure 2. The aerosol/trace gas properties and air mass history for the entire experimental period. (a) rBC mass loadings from SP2, nonrefractory compositions (sulfate, nitrate and total organic) from AMS; (b) mass median diameter (MMD) of BC cores $\left(D_{\mathrm{c}}\right)$; (c) bulk coating thickness, $D_{\mathrm{p}} / D_{\mathrm{c}}$ (see the definition in Sect. 2.1), within the $D_{\mathrm{c}}$ range $110-150 \mathrm{~nm}$, and the entire SP2 detectable $D_{\mathrm{c}}$ range $(80-600 \mathrm{~nm}$ ), with the right red axis showing the chemical age metric $-\log \left(\mathrm{NO}_{\mathrm{x}} / \mathrm{NO}_{\mathrm{y}}\right)$; (d) $\mathrm{rBC}$ mass fraction calculated as $\mathrm{rBC}$ mass $/(\mathrm{rBC}$ mass + total non-refractory mass from AMS); (e) the absorption Ångström exponent (AAE, $\alpha$ ) calculated from Aethalometer data (at $\lambda$ 's 470 and $950 \mathrm{~nm}$ ); (f) classified air mass category and the dominant regional air mass types derived from NAME modelling, with the grey line showing the local air temperature.

pure wood burning $\left(\alpha_{\mathrm{wb}}\right)$ to the Aethalometer measured $\alpha$ at $\lambda 470$ and $950 \mathrm{~nm}$ (Sandradewi et al., 2008), according to Eqs. (2a-d):

$$
\begin{aligned}
& b_{\mathrm{abs}, \mathrm{total}, \lambda}=b_{\mathrm{abs}, \mathrm{tr}, \lambda}+b_{\mathrm{abs}, \mathrm{wb}, \lambda} \\
& \frac{b_{\mathrm{abs}, \mathrm{tr}, 470 \mathrm{~nm}}}{b_{\mathrm{abs}, \mathrm{tr}, 950 \mathrm{~nm}}}=\left(\frac{470}{950}\right)^{-\alpha_{\mathrm{tr}}} \\
& \frac{b_{\mathrm{abs}, \mathrm{wb}, 470 \mathrm{~nm}}}{b_{\mathrm{abs}, \mathrm{wb}, 950 \mathrm{~nm}}}=\left(\frac{470}{950}\right)^{-\alpha_{\mathrm{wb}}} \\
& \mathrm{BC}_{\mathrm{wb}}=\mathrm{BC}_{\text {total }} \times \frac{b_{\mathrm{abs}, \mathrm{wb}, 950 \mathrm{~nm}}}{b_{\mathrm{abs}, \mathrm{total}, 950 \mathrm{~nm}}}
\end{aligned}
$$

The Aethalometer attribution method is based on the higher absorption $\lambda$ dependence of carbonaceous aerosols produced from wood burning sources compared to the fossil fuel combustion sources. A significant fraction of absorbing organic carbon aerosols (known as the brown carbon) produced from wood burning have an enhanced light absorption at shorter $\lambda$; whereas the absorption of $\mathrm{BC}$ is dominant at longer $\lambda$. The key factors for the accuracy of the model is to assign appropriate $\alpha$ values for the pure traffic and pure wood burning sources; otherwise the uncertainties of the assumed $\alpha$ will lead to considerable variations of the model outputs (Harrison et al., 2012a, 2013).

In this study, the value of $\alpha_{\mathrm{tr}}$ is obtained by the project average of the directly measured $\alpha$ (Herich et al., 2011) during the summer IOP when the site was dominated by traffic BC sources $\left(\alpha_{\mathrm{tr}}=1.04\right)$. The $\alpha$ of wood burning has been shown to exhibit a large range depending on the burning conditions, types of wood as well as aging of the biomass smoke (Saleh et al., 2013 and references therein). Given it has been impossible to obtain the real $\alpha_{\mathrm{wb}}$ value for the London urban environment, the approach of this study is to set $\alpha_{\mathrm{wb}}=1.9$ at a first instance according to Sandradewi et al. (2008), but this value will be further evaluated by externally comparing with the other mass attribution methods.

\subsection{BC source attribution by BC mass and AMS-PMF}

The AMS-PMF results are shown in Fig. 3a. These were consistent with previous observations during UK wintertime (Allan et al., 2010; Liu et al., 2011), where the organic aerosol loadings showed contributions from both traffic sources (HOA) and solid fuel burning (SFOA), the latter which is thought to be due to a combination of wood and coal burning for residential space heating. In this study, 
the contribution from solid fuel burning sources is split into SFOA I and SFOA II (Sect. 2.2). Given both solid fuel burning and traffic sources can contribute significantly to $\mathrm{BC}$ mass $\left(f_{\mathrm{BC}}\right)$, a multiple linear regression analysis was used to quantify each contributing factor, as described in Eq. (3). This is similar to the approach described by Liu et al. (2011) where the SFOA total component, described in Eq. (3), is the sum of (SFOA I) and (SFOA II). The modelled results are shown in Table 2a.

$$
f_{\mathrm{BC}}\left(\mathrm{HOA}, \mathrm{SFOA}_{\text {total }}\right)=a(\mathrm{HOA})+b\left(\mathrm{SFOA}_{\text {total }}\right)+c
$$

The regression results show that the $\mathrm{BC}$ mass in $\mathrm{W}$ air masses is dominated by the traffic source because of the large $\mathrm{BC} / \mathrm{HOA}$ derivative $(a=1.25)$. The $\mathrm{BC} / \mathrm{HOA}$ mass ratio for $\mathrm{E}$ and SE air masses was similar but reduced $(a=0.98-$ 1.08). It should be noted that there is a high background ( $c$ ) for SE air masses which will lead to large uncertainty when determining the $\mathrm{BC} / \mathrm{SFOA}_{\text {total }}$ derivative $(b)$. A regression forcing the background to zero was also tested $(c=0)$; how-

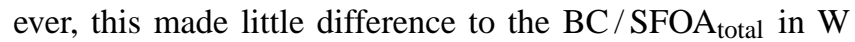
or $\mathrm{E}$ air masses, although the coefficient $b$ for $\mathrm{SE}$ air masses was increased significantly because of the added higher background. The $\mathrm{BC} / \mathrm{HOA}$ emission factor $a$ in the London urban environment is higher than that observed in Paris suburban environment $(a=0.84)$ (Laborde et al., 2013) and even higher than at a rural elevated site Holme Moss, which was downwind of Manchester and surrounding settlements ( $a=0.62 \pm 0.014$ ) (Liu et al., 2011). The BC/HOA tends to have a decreasing trend when away from the traffic sources.

The coefficient of solid fuel burning influenced factor $(b)$ was found to vary from site to site, e.g. as reported in Liu et al. (2011), $b$ was $0.51 \pm 0.009$, while Laborde et al. (2013) suggest $b$ is close to zero $(0.002 \pm 0.008)$. The variation in the mass ratio $\mathrm{BC} / \mathrm{SFOA}_{\text {total }}$ suggests the influence of additional complex SF sources but nevertheless a higher $\mathrm{BC} / \mathrm{SFOA}_{\text {total }}$ ratio will suggest a larger influence of SF, e.g. the elevated rural site, Holme Moss, was more strongly influenced by solid fuel burning from surrounding villages, while London is less so because of the proximity of the prevailing urban environment.

It is postulated that different air masses may have been influenced by different sources of solid fuel burning, and this is further examined using a tri-linear regression by dividing the solid fuel burning sector into more detailed SFOA I and SFOA II, factors as expressed in Eq. (4):

$$
\begin{aligned}
& f_{\mathrm{BC}}(\mathrm{HOA}, \mathrm{SFOAI}, \mathrm{SFOAII})= \\
& i(\mathrm{HOA})+j(\mathrm{SFOAI})+k(\mathrm{SFOAII})+l .
\end{aligned}
$$

The $\mathrm{BC}$ from solid fuel burning $\left(\mathrm{BC}_{\mathrm{sf}}\right)$ mass fraction is calculated as the fraction of $j(\mathrm{SFOA} \mathrm{I})+k(\mathrm{SFOA}$ II) from the tri-linear regression, as Fig. 3c shows. The retrieved mass ratio $\mathrm{BC} / \mathrm{SFOAII}(k)$ suggests the SFOAII factor significantly influences both the $\mathrm{W}$ and $\mathrm{E}$ air masses (Table 2b), but interestingly for $\mathrm{E}$ air masses a higher BC / SFOAI is found $(j=0.33)$, whereas the SFOAI sector influence in $\mathrm{W}$ air masses is low $(j=0.09)$. This suggests the prevalence of BC from the SFOAII for both $\mathrm{W}$ and $\mathrm{E}$ air masses; however, an additional SF source appears to be only present during $\mathrm{E}$ air masses. This additional solid fuel burning is of a similar magnitude to the SFOAII source. If we assume that the towns and villages surrounding London use similar space heating fuel sources, this additional solid fuel burning source will have arrived at the site through regional transport. The tri-linear regression however does not improve the background level for SE air masses, but the background-forcing zero regression suggest SFOA I $(j=0.21)$ and SFOA II $(k=0.27)$ both significantly influence the measurement site. However, the high background with SE air masses may be due to the complex meteorological conditions or possible multiple sources that cannot be well resolved by the BC-AMS-PMF analysis. Given the split of SFOA could be explained as different burn phases (Young et al., 2014), the SFOA from W air mass may have been dominant by one burn phase, whereas for $\mathrm{E}$ air masses, multiple burn phases could have influenced the site.

\subsection{BC physical properties and source attribution by SP2}

The coating thickness for a given single BC particle is obtained by using an inverse Mie scattering model in conjunction with the $\mathrm{BC}$ core size to obtain the equivalent diameter of a sphere with the $\mathrm{BC}$ assumed to be a concentric spherical inclusion and with the same scattering cross section as the measured particle after LEO fitting, as described by Taylor et al. (2014). The first step of this approach is to validate the $\mathrm{BC}$ core refractive index $(m)$ against ambient particles at the SP2 incident light wavelength $(\lambda=1064 \mathrm{~nm})$. The optimum value of $m$ for BC core was validated by comparing the measured scattering signal with the modelled scattering of the uncoated $\mathrm{BC}$ core for the particles after passing through a thermodenuder (TD, Huffman et al., 2008) at a temperature of $250^{\circ} \mathrm{C}$, and by assuming any coatings associated with $\mathrm{BC}$ particles were subsequently removed; that is, the scattering signal of these assumed uncoated $\mathrm{BC}$ particles should be equal to the Mie calculated scattering of the $\mathrm{BC}$ core; and the determination of the $m$ of $\mathrm{BC}$ core using this method is largely independent of the uncertain particle shape effect at $\lambda=1064 \mathrm{~nm}$ (Moteki et al., 2010).

To better illustrate this methodology, a parameter of scattering enhancement, $E_{\mathrm{S}}$, is introduced, which is defined by Eq. (5):

$E_{\mathrm{s}}=\frac{S_{\text {coated }}}{S_{\text {uncoated }}^{*}}$,

where $S_{\text {coated }}$ is the scattering signal measured from the SP2 and then LEO fitted. $S_{\text {uncoated }}^{*}$ is the scattering signal of the corresponding $\mathrm{BC}$ core, with the asterisk denoting it is calculated using the Mie single particle scattering solutions. 


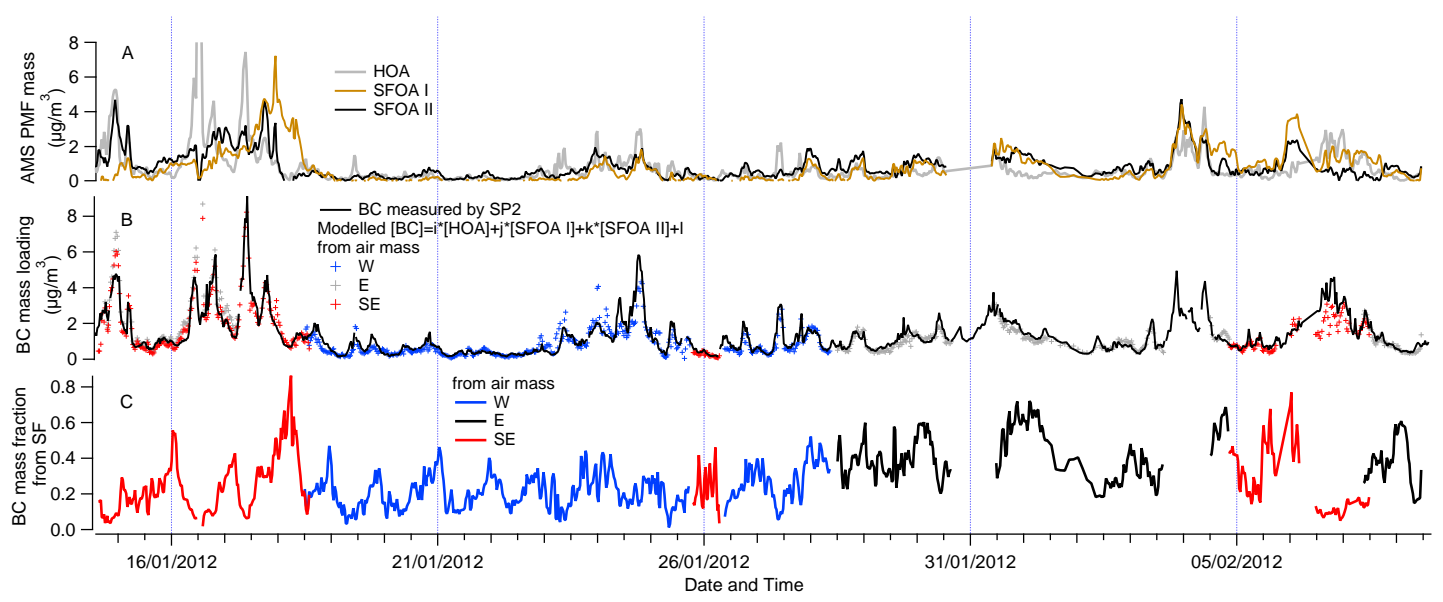

Figure 3. (a) Time series of AMS-PMF mass loading results for HOA, SFOA I and SFOA II; (b) Modelled BC mass by tri-linear regression compared with the measurements for different air masses (note the bi-linear regression is also tested but not shown in this figure); (c) $\mathrm{BC}-\mathrm{AMS}-\mathrm{PMF}$ attributed $\mathrm{BC}_{\mathrm{sf}}$ mass fraction by tri-linear regression.

Table 2. (A) The bi-linear regression results for the BC-AMS-PMF attribution. (B) The tri-linear regression results for the BC-AMS-PMF attribution. ${ }^{*}$ Denotes an orthogonal distance regression (ODR).

\begin{tabular}{lccccc}
\hline (A) & $a$ & $b$ & $c$ & $a_{0}(c=0)$ & $b_{0}(c=0)$ \\
\hline Westerly & $1.25 \pm 0.06$ & $0.13 \pm 0.03$ & $0.13 \pm 0.03$ & $1.32 \pm 0.05$ & $0.15 \pm 0.03$ \\
Easterly & $1.08 \pm 0.06$ & $0.22 \pm 0.02$ & $0.08 \pm 0.04$ & $1.14 \pm 0.05$ & $0.20 \pm 0.01$ \\
Southeasterly & $0.98 \pm 0.02$ & $0.06 \pm 0.01$ & $0.41 \pm 0.05$ & $1.05 \pm 0.02$ & $0.12 \pm 0.01$ \\
\hline (B) & $i$ & $j$ & $k$ & $l$ & \\
\hline Westerly & $1.18 \pm 0.06$ & $0.094 \pm 0.126$ & $0.37 \pm 0.11$ & $0.094 \pm 0.04$ & \\
Easterly & $1.07 \pm 0.06$ & $0.33 \pm 0.0354$ & $0.23 \pm 0.049$ & $0.10 \pm 0.0435$ & \\
Southeasterly & $0.99 \pm 0.03$ & $0.12 \pm 0.0244$ & $0.025 \pm 0.04$ & $0.40 \pm 0.0458$ & \\
\hline & $i_{0}(l=0)$ & $j_{0}(l=0)$ & $k_{0}(l=0)$ & $\mathrm{Modelled}$ results & \\
\hline Westerly & $1.22 \pm 0.054$ & $0.012 \pm 0.13$ & $0.52 \pm 0.083$ & $\mathrm{BC}_{\text {model }}=0.82^{*} \mathrm{BC}_{\text {measured }}$ (offset $\left.=0.094\right)$ \\
Easterly & $1.02 \pm 0.030$ & $0.36 \pm 0.020$ & $0.30 \pm 0.022$ & $\mathrm{BC}_{\text {model }}=0.91^{*} \mathrm{BC}_{\text {measured }}($ offset $=0.062)$ \\
Southeasterly & $0.83 \pm 0.024$ & $0.21 \pm 0.02$ & $0.27 \pm 0.035$ & $\mathrm{BC}_{\text {model }}=0.98^{*} \mathrm{BC}_{\text {measured }}$ (offset $\left.=-0.15\right)$ \\
\hline
\end{tabular}

According to this definition, a value of $E_{\mathrm{s}}=1$ means that a $\mathrm{BC}$ particle scatters equivalently to that containing only a $\mathrm{BC}$ core, in other words has zero coating or $D_{\mathrm{p}} / D_{\mathrm{c}}=1$. In reality, particles with any associated coatings will scatter more than the core, thus $E_{\mathrm{s}}$ will be necessarily $>1$; however, $S_{\text {coated }}$ will also be subject to instrument measurement uncertainty, thus a fraction of particles with of $E_{\mathrm{s}}$ with $<1$ would be expected. An increase of $E_{\mathrm{s}}$ will in general indicate a thicker coating thickness for a specified $D_{\mathrm{c}}$.

The variation of $E_{\mathrm{S}}$ as a function of BC core diameter $\left(D_{\mathrm{c}}\right)$ is shown in Fig. 4a, for the particles when the traffic source is mostly dominant (Fig. 3c) and the BC particles were least coated (Fig. 2c) during the experiment. The coatings associated with these $\mathrm{BC}$ particles are deemed to be completely removed after thermal desorption at $250{ }^{\circ} \mathrm{C}$ (hereafter referred to as $\mathrm{TD} 250{ }^{\circ} \mathrm{C}$ ), in other words, the zero coating should yield $E_{\mathrm{S}}=1$. This hypothesis was tested on the $\mathrm{TD} 250{ }^{\circ} \mathrm{C}$ traffic-dominant $\mathrm{BC}$ by varying the refractive index $(m)$ of
BC core using a selection of different values of $m$ reported in the literature (Taylor et al., 2014). It was found that the value of $m=2.26-2.16 i$ reported by Moteki et al. (2010) for $\mathrm{BC}$ core at SP2 wavelength $\lambda=1064 \mathrm{~nm}$, produced the best agreement between the measured scattering and Mie model throughout the detectable $D_{\mathrm{c}}$ range, as shown in Fig. 4a. The slightly increasing trend towards smaller $D_{\mathrm{c}}(<110 \mathrm{~nm})$ is due to the low signal-to-noise ratio in the scattering signal associated with the SP2 detectors, in turn causing a failed LEO fit due to undetectable notch position (see Supplement), or the measured particle scattering signal falling outside of the Mie predictable range. It is expected that the scattering signals for a fraction of smaller BC particles $\left(D_{\mathrm{c}}<110 \mathrm{~nm}\right)$ associated with thin coatings have also not been efficiently detected, thus resulting in a bias in the particles that were successfully fitted towards those with larger cores.

The coated BC diameter $\left(D_{\mathrm{p}}\right)$ is calculated here using the $\mathrm{BC}$ core refractive index $(m)=2.26-1.26 i$ and the coating 

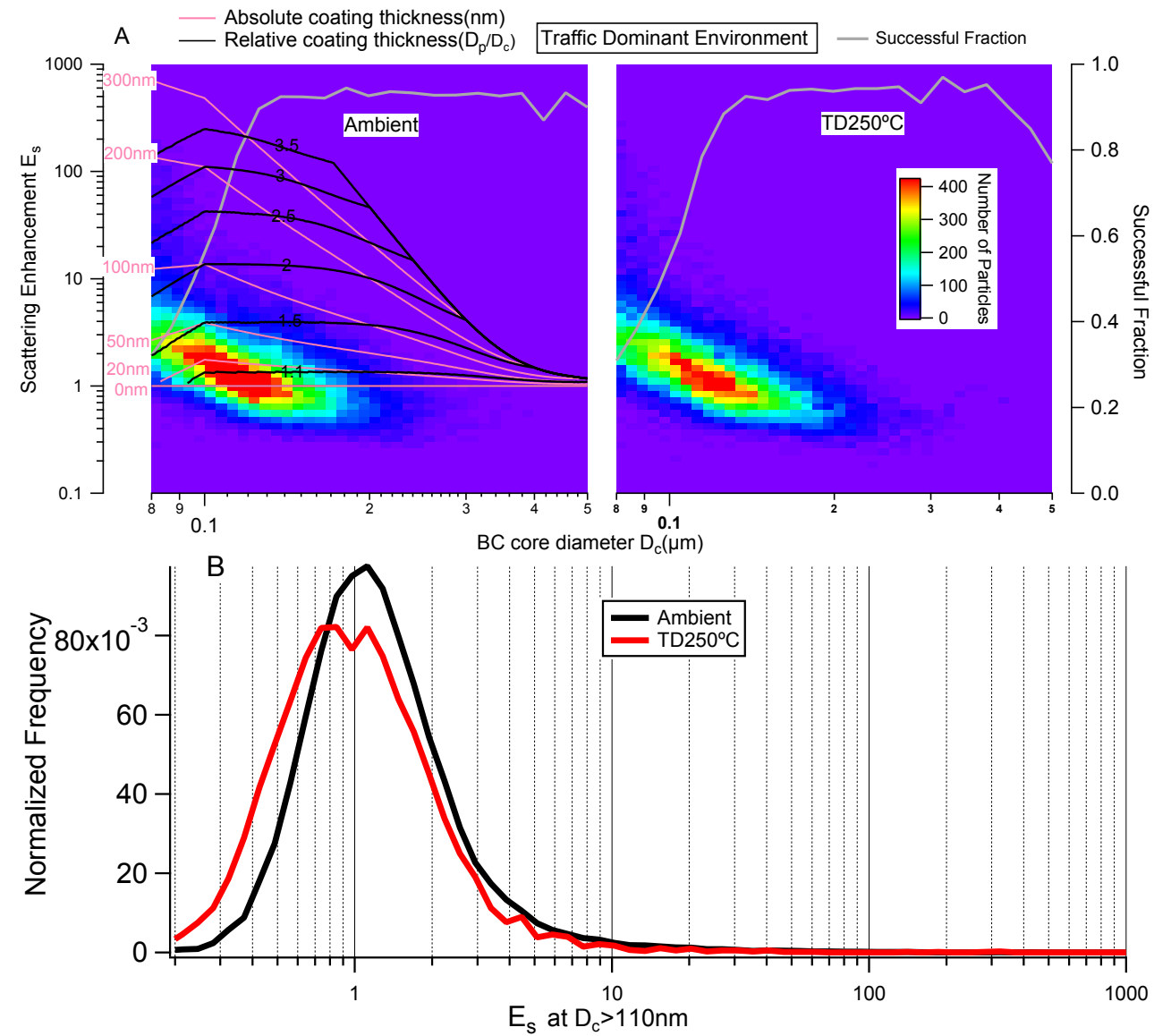

Figure 4. BC optical properties when the environment is dominated by traffic source (22 to 24 January during W air masses). (a) The scattering enhancement $\left(E_{\mathrm{S}}\right)$ as a function of $\mathrm{BC}$ core diameter $\left(D_{\mathrm{c}}\right)$. The image plot is a two dimensional histogram for the detected particles. The solid grey line, with corresponding scale on right axis, shows the number fraction of BC particles that were successfully determined according to their scattering signal at each $D_{\mathrm{c}}$ size. The left panel is for the ambient data, whereas the right panel is the same group of $\mathrm{BC}$ particles after passing through the thermodenuder (TD) at $250^{\circ} \mathrm{C}$. The thinner red and black contours show the corresponding absolute coating thickness (in $\left.\mathrm{nm},\left(D_{\mathrm{p}}-D_{\mathrm{c}}\right) / 2\right)$ and relative coating thickness $\left(D_{\mathrm{p}} / D_{\mathrm{c}}\right)$, respectively. (b) The area normalised histogram of $E_{\mathrm{S}}$ for the particles with $D_{\mathrm{c}}>110 \mathrm{~nm}$.

refractive index $m=1.48+0 i$. The coating refractive index has been verified as being representative of ambient scattering aerosols (Taylor et al., 2014; Laborde et al., 2013), and is also applied to calculate the optical size of non-BC particles. The corresponding coating thickness in terms of absolute $\left(D_{\mathrm{p}}-D_{\mathrm{c}}\right) / 2$ and relative coating thickness $\left(D_{\mathrm{p}} / D_{\mathrm{c}}\right)$ is mapped to the scattering enhancement, $E_{\mathrm{s}}$, as a function of BC core diameter, $D_{\mathrm{c}}$, as shown in Fig. $4 \mathrm{a}$.

The refractive index of $\mathrm{BC}$ core for the traffic-dominant source may not necessarily apply for the solid fuel burning $\mathrm{BC}$ core; however, this hypothesis is impossible to test here, as under the current TD setting $\left(\mathrm{TD} 250^{\circ} \mathrm{C}\right)$, the coatings associated with solid fuel burning $\mathrm{BC}$ have not been completely removed, as shown in Fig. 5. The BC particles after $\mathrm{TD} 250^{\circ} \mathrm{C}$ exposure appear to have been compacted to a single well-defined mode; however, a significant tail in the $E_{\mathrm{S}}$ distribution (Fig. 5b) remains. The remaining coatings as- sociated with $\mathrm{BC}$ after $\mathrm{TD} 250{ }^{\circ} \mathrm{C}$, when solid fuel burning dominates, may still contain a significant fraction of lessvolatile organic matter. For the ambient data that is largely influenced by solid fuel burning, there are clearly two modes of $\mathrm{BC}$ particle populations with different physical properties (Fig. 5a). The mode with smaller BC core size and thinner coatings matches well with the single-mode traffic-dominant source (Fig. 4a). The BC particles making up this mode are deemed to be mainly from the traffic source, whereas the other mode with larger BC core size and thicker coatings are considered to be from solid fuel burning. It has been reported that the $\mathrm{BC}$ from biomass burning is initially thickly coated using SP2 measurements (e.g. Schwarz et al., 2008; Sahu et al., 2012), and these London results are consistent with this and support the contention that the solid fuel burning source will strongly control the variation of $\mathrm{BC}$ core size 

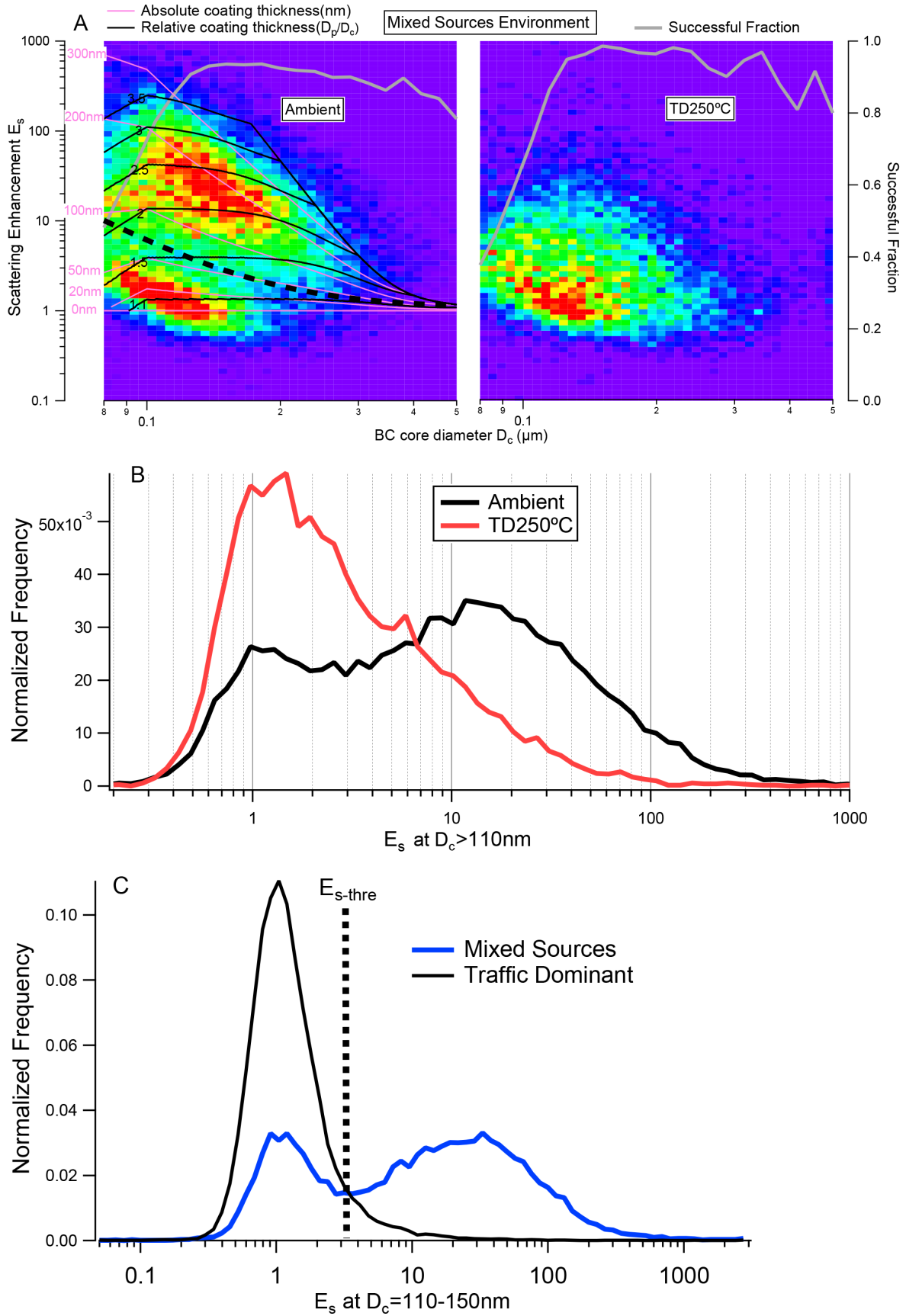

Figure 5. BC optical properties when environment is significantly influenced by solid fuel burning (31 January to 1 February when E air mass). The legends in the plot are identical with Fig. 4. In particular, the thick dotted black line on the left panel of (a) shows the reference line used to discriminate the $\mathrm{BC}$ from traffic or solid fuel burning source. (c) the $E_{\mathrm{s}}$ distribution at $D_{\mathrm{c}}=110-150 \mathrm{~nm}$ for the traffic and mixed sources, with the dotted line showing the determination of $E_{\mathrm{s}-\mathrm{thre}}$.

and coating thickness, i.e. significantly increase the $\mathrm{BC}$ core size and coating thickness.

Based on the determined $E_{\mathrm{s}}$ as a function of $D_{\mathrm{c}}$ size, at each binned $D_{\mathrm{c}}$ size, a threshold scattering enhancement $E_{\text {s-thre }}$ can be obtained from the minima of each $E_{\mathrm{s}}$ distribution (within $1<E_{\mathrm{s}}<30$ ). Figure $5 \mathrm{c}$ shows an example of how
$E_{\mathrm{s}-\text { thre }}$ is determined at a specified $D_{\mathrm{c}}$. The $E_{\mathrm{s} \text {-thre }}$ as a function of $D_{\mathrm{c}}$ can then be empirically fitted as a power function:

$E_{\mathrm{S}-\mathrm{thre}}=1.0637+0.012343 \cdot D_{\mathrm{c}}^{-2.6131}$.

For a given size of $D_{\mathrm{c}}$, any $\mathrm{BC}$ particle with $E_{\mathrm{s}}>\mathrm{E}_{\mathrm{s} \text {-thre }}$ is considered to be the $\mathrm{BC}$ from non-traffic sources in this 

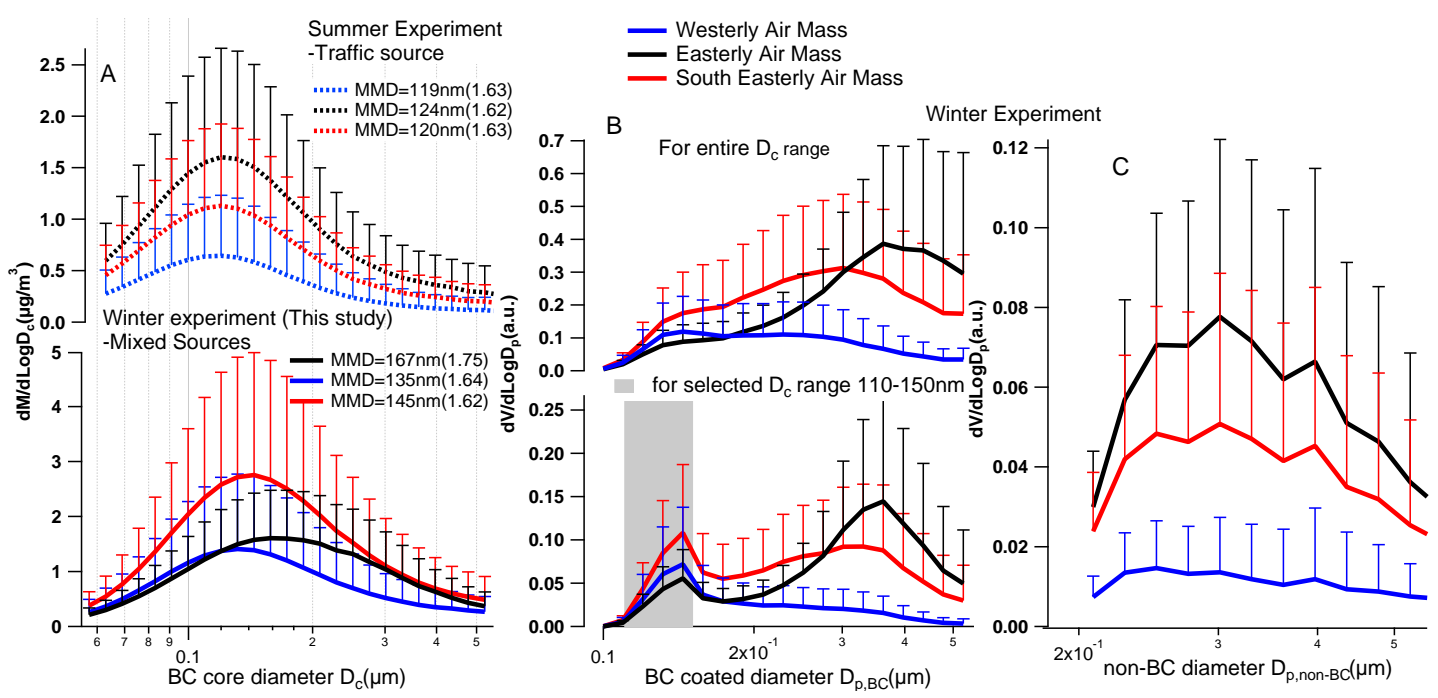

Figure 6. BC-related size distributions classified by air masses. The error bar are the $+\sigma$ (standard deviation) and the value in brackets is the geometric standard deviation $\left(\sigma_{\mathrm{g}}\right)$ for each size distribution: (a) BC core $\left(D_{\mathrm{c}}\right)$ size distribution for both winter and summer experiments, with the dotted lines showing the summer experiment; the text boxes denote the mass median diameter, MMD, and the geometric mean $\sigma_{\mathrm{g}}$ (in brackets) for each size distribution; (b) coated BC size $\left(D_{\mathrm{p}}\right)$ distribution for the selected $D_{\mathrm{c}}$ range, $110-150 \mathrm{~nm}$ (with the grey shaded box showing the range of values) and for the entire detectable $D_{\mathrm{c}}$ range in winter; (c) the size distribution of non-BC particles which do not contain $\mathrm{BC}$ core in winter.

model, based on the assumption that for a given source, the coating thickness distribution is unimodal at the point of emission. The $E_{\mathrm{s} \text {-thre }}$ as a function of $D_{\mathrm{c}}$ is shown as the dark dotted line in the left panel of Fig. 5a, the BC particles above the line are grouped as the $\mathrm{BC}$ from solid fuel burning $\left(\mathrm{BC}_{\mathrm{sf}}\right)$ and below the line is the $\mathrm{BC}$ from traffic $\left(\mathrm{BC}_{\mathrm{tr}}\right)$.

$\mathrm{A}$ fraction of aged $\mathrm{BC}_{\mathrm{tr}}$ with thicker coatings may lie beyond the $E_{\mathrm{s} \text {-thre }}$ reference line hence the $\mathrm{BC}_{\text {tr }}$ will be underestimated. It has been shown previously that the diagnostic $-\log \left(\mathrm{NO}_{\mathrm{x}} / \mathrm{NO}_{\mathrm{y}}\right)$ is positively correlated with $\mathrm{BC}$ coating thickness, e.g. as reported during the CalNex project (Cappa et al., 2012), when the measurement site was mainly influenced by traffic sources and also experiencing strong photochemical activity. The ageing scale of $\mathrm{BC}$ during the London experiment was also examined using this metric, as Fig. 2c shows. Only a very weak correlation between BC coating thickness and $-\log \left(\mathrm{NO}_{\mathrm{x}} / \mathrm{NO}_{\mathrm{y}}\right)$ was observed for $\mathrm{W}$ air mass $\left(r^{2}=0.15\right)$ when the site was less influenced by solid fuel burning (SFOA / HOA < 3), but for the rest of the period no correlation was found, i.e. for the $\mathrm{E}$ air mass, the significant increase of $\mathrm{BC}$ coating thickness is not associated with an increase in $-\log \left(\mathrm{NO}_{\mathrm{x}} / \mathrm{NO}_{\mathrm{y}}\right)$ from 28 January to 2 February. In any event, even an increase in $-\log \left(\mathrm{NO}_{\mathrm{x}} / \mathrm{NO}_{\mathrm{y}}\right)$ from 0.04 to 0.13 will only result in a maximum variation in the $\mathrm{BC}_{\mathrm{tr}}$ number fraction of $<5 \%$. Furthermore, the generally much lower $-\log \left(\mathrm{NO}_{\mathrm{x}} / \mathrm{NO}_{\mathrm{y}}\right)$ found in the winter IOP compared with the summer IOP suggests the majority of BC are local from primary sources rather than aged $\mathrm{BC}$ during wintertime (as further discussed below). The ageing influence on this BC mass attribution model is thus deemed to be low.
$\mathrm{BC}_{\mathrm{sf}}$ may also contain some fraction of $\mathrm{BC}$ with thinner coatings that is located below the $E_{\text {s-thre }}$ threshold used here, which will compensate the postulation above.

The mass median diameter of black carbon core (MMD, with the value in brackets denoting the geometric standard deviation $\sigma_{\mathrm{g}}$ ) of $\mathrm{W}, \mathrm{SE}$ and $\mathrm{E}$ air masses are $135 \mathrm{~nm}$ (1.64), $145 \mathrm{~nm}$ (1.62) and $167 \mathrm{~nm}$ (1.75), respectively. The broader $D_{\mathrm{c}}$ distribution $\left(\sigma_{\mathrm{g}}=1.75\right)$ when $\mathrm{E}$ air mass suggests more mixed BC sources, whereas for Westerlies it is more likely to be comprised of less mixed sources. One may postulate that the increased $\mathrm{BC}$ core size is possibly the result of the ageing/coagulation of $\mathrm{BC}$; however, a close comparison with the summer data set largely excludes this possibility, as shown in the upper panel of Fig. 6a. The experiment was repeated at the same location in summertime, and the air masses classified in the same manner. It can be clearly seen that the $D_{\mathrm{c}}$ size distribution in summer was independent of the air masses (little variation in MMD and $\sigma_{\mathrm{g}}$, , because during summer the $\mathrm{BC}$ source was dominated by traffic emissions and solid fuel burning sources were almost absent. Given that in summertime, we expect stronger photochemical activity compared to wintertime, the similar $D_{\mathrm{c}}$ size observed during summer suggests little influence by ageing processes on the mono-source of $\mathrm{BC}$, further supporting the presence of the stronger nontraffic source during wintertime.

The winter/summer results suggest that self-coagulation of BC (that leads to the enlargement of $D_{\mathrm{c}}$ ) is fairly weak following emission and during transport. The coagulation process of $\mathrm{BC}$ may have been only significant at the emission stage when the $\mathrm{BC}$ concentration is high, which cannot be 
observed at the receiving site. It is possible that the ageing scale or transport range observed at this urban site may not be long enough to lead to a significant increase in $D_{\text {c }}$. However, the larger $\mathrm{BC}$ cores will be preferentially removed by wet deposition (Moteki et al., 2012), and if so the scavenged reservoir of $\mathrm{BC}$ after ageing/transport will tend towards even smaller $D_{\mathrm{c}}$ compared to initial emission sources.

The coated BC optical size $\left(D_{\mathrm{p}}\right)$ distribution is shown in Fig. 6b. Consistent with Fig. $4 \mathrm{a}$, when $\mathrm{W}$ air masses, the $D_{\mathrm{p}}$ size within the $D_{\mathrm{c}}$ range $110-150 \mathrm{~nm}$ shows mainly a single BC mode without a significant $D_{\mathrm{p}}$ shift, resulting in a main mode with $D_{\mathrm{p}} / D_{\mathrm{c}} \sim 1$ with a minor tail extending to larger $D_{\mathrm{p}}$. Consistent with Fig. 5a, the E and SE air mass results show apparent bimodal $D_{\mathrm{p}}$ distributions, i.e. for $\mathrm{E}$ air mass, the larger mode in $D_{\mathrm{p}}$ peaks at $\sim 360 \mathrm{~nm}$, clearly indicating a thicker coating for the majority of the $\mathrm{BC}$ particles. The $D_{\mathrm{p}}$ size distributions over the entire $D_{\mathrm{c}}$ range exhibit a clear increase in coated BC size as expected for the W-SE-E air masses, peaking at $\sim 140,300$ and $360 \mathrm{~nm}$ respectively. There is no clear variation of size for the non-BC particles in all air masses (which peak $~ 300 \mathrm{~nm}$, Fig. 6c).

With the assumption that the traffic-dominant BC will exhibit a consistent and stable $D_{\mathrm{c}}$ size distribution, the $\mathrm{BC}$ mass attribution using the $E_{\mathrm{s} \text {-thre }}-D_{\mathrm{c}}$ model is further verified by comparing the separated $\mathrm{BC}_{\mathrm{tr}}$ size distribution from mixed sources and the $\mathrm{BC}$ size distribution when the site is less influenced by solid fuel burning (number fraction of $\mathrm{BC}_{\mathrm{sf}}<5 \%$ ), as shown in Fig. 7. The attributed $\mathrm{BC}_{\mathrm{tr}}$ size distribution from mixed sources compares well with the trafficdominant $\mathrm{BC}$ size distribution, but the size of attributed $\mathrm{BC}_{\mathrm{tr}}$ is only slightly larger because the classification is not perfect, i.e. some $\mathrm{BC}_{\mathrm{sf}}$ may have been included in the modelled $\mathrm{BC}_{\mathrm{tr}}$. The $\mathrm{BC}$ core sizes measured in summer were smaller compared to the winter, because these had no detectable influences from SF. The attributed $\mathrm{BC}_{\mathrm{sf}}$ core peaked at $D_{\mathrm{c}} \sim 210 \mathrm{~nm}$.

The SF source strongly affects the BC-related properties, as summarised in Fig. 8. Increased $\mathrm{BC}_{\mathrm{sf}}$ mass fractions enlarge $D_{\mathrm{c}}$ and increase the coating thickness of BC. It is interesting to note that an increase in SF influence has decreased the BC mass fraction (Fig. 8e) while the SF source contains more non-BC particles (Fig. 8f). The SF source produces a larger fraction of particles that do not contain a BC core, which is consistent with other studies (e.g. Kondo et al., 2011) which show that a significant fraction of non-BC particles are emitted with SF particles, and these non-BC particles may have contributed to the thicker coating thickness of $\mathrm{BC}_{\mathrm{sf}}$ particles through coagulation (Kondo et al., 2011).

In order of air masses $\mathrm{W}-\mathrm{SE}-\mathrm{E}$ (i.e. $\mathrm{BC}_{\mathrm{sf}}$ mass fraction ranging from low to high), $D_{\mathrm{c}}$ was found to range from $137 \pm 10 \mathrm{~nm}, 143 \pm 11 \mathrm{~nm}$ and $169 \pm 29 \mathrm{~nm}$, respectively, while the associated bulk relative coating thicknesses $\left(D_{\mathrm{p}} / D_{\mathrm{c}}\right)$ were $1.28 \pm 0.07,1.45 \pm 0.16$ and $1.65 \pm 0.19$. The $\mathrm{BC}_{\mathrm{sf}}$ number fraction in order of $\mathrm{W}-\mathrm{SE}-\mathrm{E}$ air masses was $6 \pm 2 \%, 11 \pm 5 \%$ and $18 \pm 10 \%$, but importantly the larger

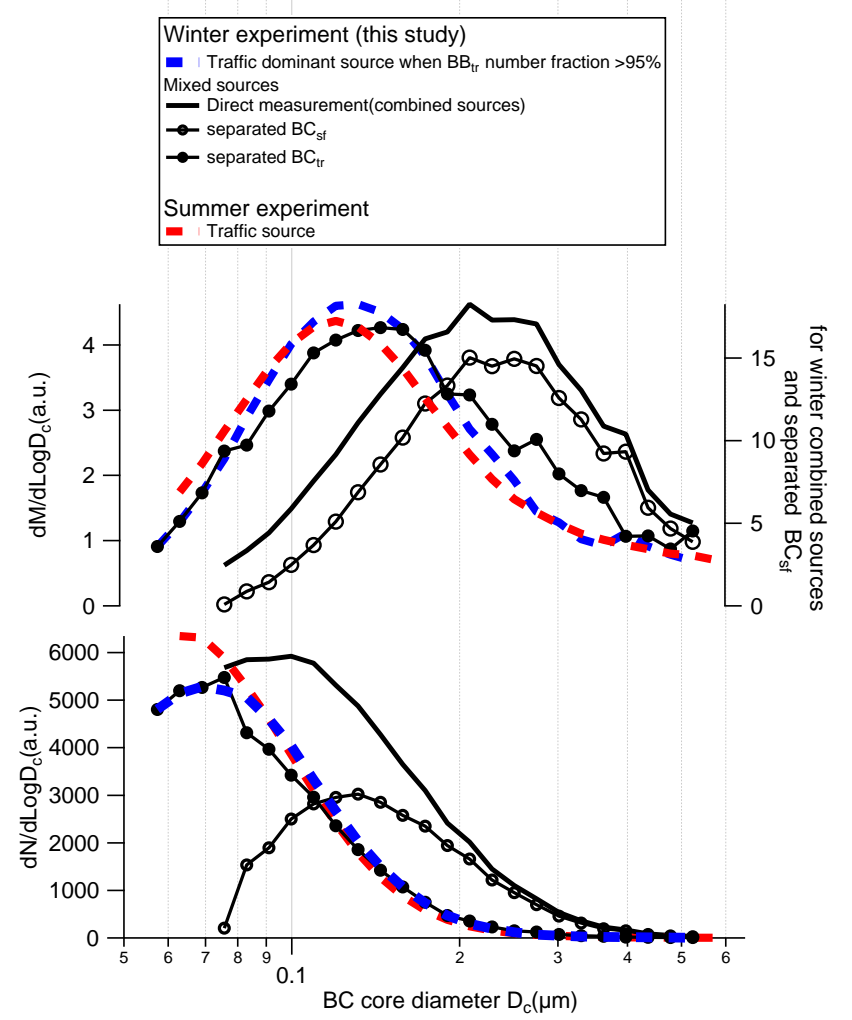

Figure 7. Mass and number size distributions of $\mathrm{BC}$ core: when traffic dominant source during winter; attributed $\mathrm{BC}_{\mathrm{tr}}$ and $\mathrm{BC}_{\mathrm{sf}}$ from mixed sources; and the $\mathrm{BC}$ in summer experiment when traffic source dominant.

$\mathrm{BC}$ core size of $\mathrm{BC}_{\mathrm{sf}}$ leads to higher fractions in terms of mass at $16 \pm 6 \%, 24 \pm 10 \%$ and $39 \pm 14 \%$ (Table 1). The $\mathrm{BC}_{\text {sf }}$ mass fraction reported in this study (overall average $26 \pm 13 \%$ ) is generally consistent with those reported from urban environments by the other studies, e.g. in Grenoble, France (average $\sim 20 \%$, Favez et al., 2010), and the longterm observations for three cities in Switzerland, 24-33\% (Herich et al., 2011), while they are lower than seen in rural environment, e.g. in Roveredo, Switzerland (51\%, Sandradewi et al., 2008) and at Holme Moss, UK (45\%, Liu et al., 2011). However, they are higher than observed in the Paris urban environment $\left(15 \% \mathrm{BC}_{\mathrm{sf}}\right.$ by Healy et al., 2012; only minor $\mathrm{BC}_{\mathrm{sf}}$ by Laborde et al., 2013).

\section{Discussions}

\subsection{The diurnal variations of $\mathrm{BC}$-related properties}

To investigate the influences of local sources under different synoptic conditions, a detailed diurnal analysis was performed and is shown in Fig. 9. The BC mass loadings all show similar trends with the first peak coinciding with the 


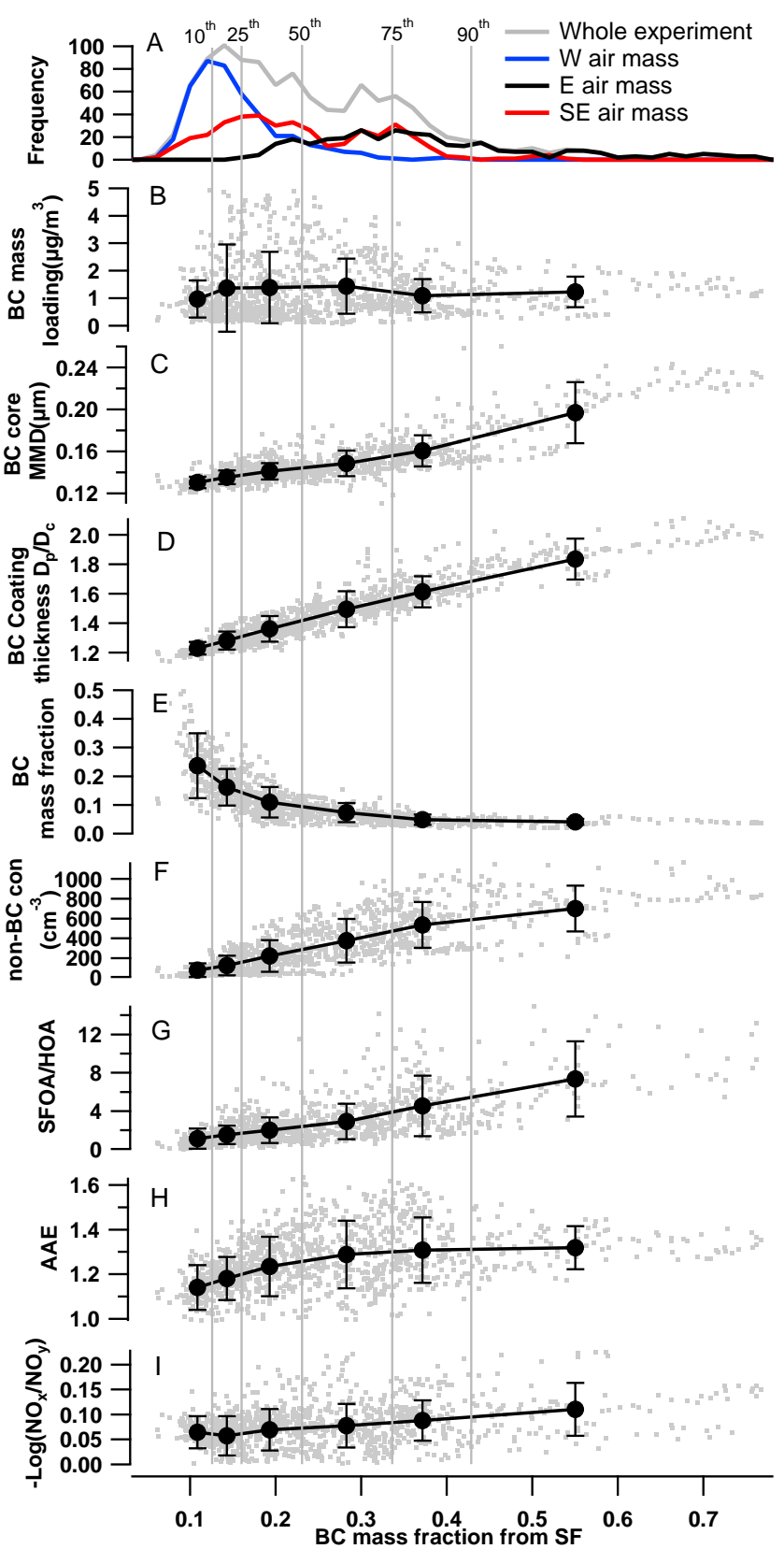

Figure 8. The $\mathrm{BC}$-related properties as a function of $\mathrm{BC}_{\mathrm{sf}}$ mass fraction as attributed by the SP2. The data points are grouped according to the percentiles of $\mathrm{BC}_{\mathrm{sf}}$ mass fraction, i.e. min to 10th percentile of $\mathrm{BC}_{\mathrm{sf}}$ fraction; 10th to 25 th percentile of $\mathrm{BC}_{\mathrm{sf}}$ fraction, etc. Each solid round marker shows the average within the grouped points with the error bar showing the standard deviation $( \pm \sigma)$. (a) of the histograms of $\mathrm{BC}_{\mathrm{sf}}$ mass fraction for $\mathrm{W}, \mathrm{E}, \mathrm{SE}$ air mass and for the entire experiment; (b) $\mathrm{BC}$ mass loadings; (c) $\mathrm{BC}$ core diameter; (d) BC coating thickness; (e) BC mass fraction; (f) non-BC concentration at 200-530 nm; (g) SFOA / HOA from AMS-PMF analysis; (h) the absorption Angström exponent calculated at $\lambda=470$ and $950 \mathrm{~nm}$; (i) $-\log \left(\mathrm{NO}_{\mathrm{x}} / \mathrm{NO}_{\mathrm{y}}\right)$.

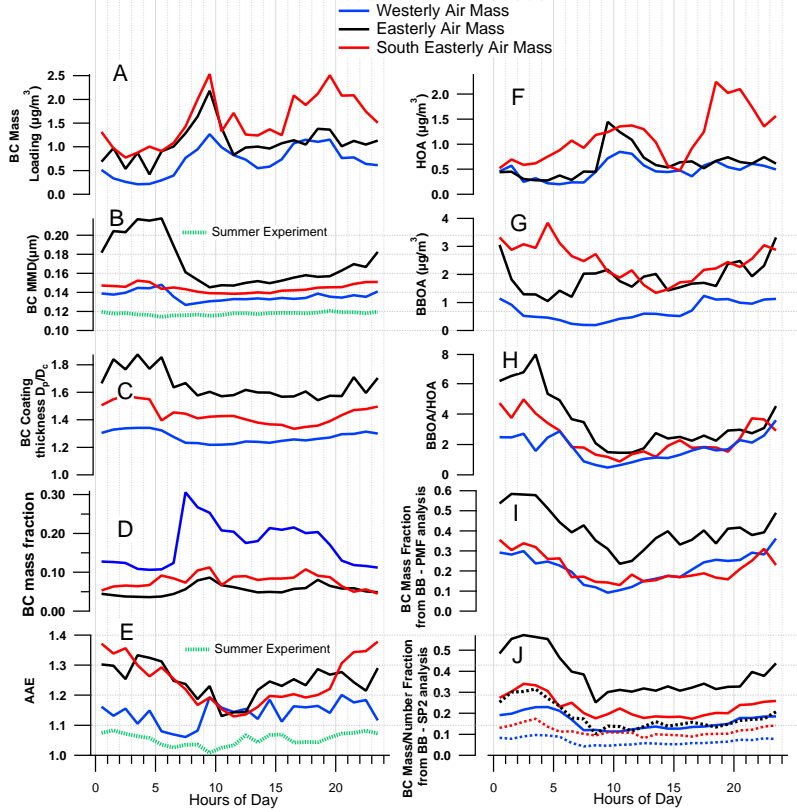

Figure 9. The diurnal trends of BC-related parameters classified by air mass. The lines show the median values of the data set. (a) rBC mass loading; (b) BC core MMD, with the dotted green line showing the summer result; (c) BC coating thickness $D_{\mathrm{p}} / D_{\mathrm{c}}$; (d) $\mathrm{BC}$ mass fraction; (e) the absorption Ångström exponent with dotted green line showing the summer result; (f) HOA mass loading from AMS-PMF; (g) SFOA total (SFOA I+SFOA II) mass loading from AMS-PMF; (h) $\mathrm{SFOA}_{\text {total }} / \mathrm{HOA}$ ratio; (i) $\mathrm{BC}$ mass fraction from solid fuel burning attributed by BC-AMS-PMF method (Sect. 3.3); and (j) BC mass/number fraction from solid fuel burning attributed by SP2 method (Sect. 3.5), with the dotted lines showing the number fraction.

morning rush hour and a later peak starting from late afternoon (Fig. 9a). The BC morning peak corresponds with the HOA peak (Fig. 9f) suggesting the main source for all three types of air mass is traffic. The BC evening peak corresponds with elevated SFOA for $\mathrm{W}$ and $\mathrm{E}$ air masses (Fig. 9g), suggesting the additional important contributing sources of solid fuel burning (SF) in the evening. However, the SE air mass shows somewhat different behaviour with a higher HOA peak from late afternoon and significant SFOA from early evening onwards throughout midnight. The significance of the SF influence is shown in the first order using SFOA/HOA (Fig. 9h), showing a clear consistent trend with the lowest SF influence occurring with morning rush hour but with increased influence due to SF starting from late afternoon, and with SF dominating at midnight. The source attribution of BC mass using both SP2 (Sect. 3.4) and BCAMS-PMF methodology (Sect. 3.3) shows a similar trend (Fig. 9i and j). These diurnal trends are generally consistent with the previous study by Allan et al. (2010) and Liu 
et al. (2011) where the site was also influenced by both traffic source and solid fuel burning.

Consistent with the view that $\mathrm{BC}$ from the traffic source is associated with particles with a smaller BC core and less coated compared to BC particles from solid fuel burning, the smallest $D_{\mathrm{c}}$ (Fig. 9b) and thinnest coatings (Fig. 9c) coincided with the morning rush hour and the increasing SF influence then leads to an increased $D_{\mathrm{c}}$ size and coating thickness. It is noted that the $D_{\mathrm{c}}$ size variation is not apparent for SE air masses. The diurnal variation of $D_{\mathrm{c}}$ size in the summer experiment is also included for reference: the $\mathrm{BC}$ measured in summer exhibited smaller $D_{\mathrm{c}}$ size with weak variation throughout the day. The larger $D_{\mathrm{c}}$ size observed in winter for all of the air masses suggests the ubiquitous and increasing influence of SF during winter which will result in a higher absorption Ångström exponent $(\alpha)$. The lowest $\alpha$ was observed at morning rush hour for E and SE (Fig. 9e) air masses; however, there was no apparent variation in $\alpha$ for $\mathrm{W}$ air masses (but lower $\alpha$ for $\mathrm{W}$ ), possibly because the SF fraction was not large enough to make a measurable change. The value of $\alpha$ in summer was lower throughout the day, again consistent with the ubiquitous influence of SF only in winter. It is also noted that although $\mathrm{E}$ air masses had the highest fraction of SF, the associated $\alpha$ did not show a higher $\alpha$, i.e. throughout midnight periods the $\alpha$ for $\mathrm{E}$ air masses was lower than that from SE air masses. This indicate that the $\mathrm{E}$ air masses may contain additional sources which exhibit lower $\alpha$ : Saleh et al. (2013) showed that the $\alpha$ for fresh biomass smoke can be lower than 1.5, and comparison with Aethalometer data in Switzerland (Zotter et al., 2014) also showed that the $\alpha$ for wood burning can vary significantly (1.2-2.1).

\subsection{Intercomparisons of BC source attribution techniques}

An intercomparison among the $\mathrm{BC}$ source attribution techniques, including the SP2 attribution, BC-AMS-PMF and Aethalometer method, is shown in Fig. 10. The Aethalometer attribution is calculated at both $470-950$ and $370-880 \mathrm{~nm}$, based on an assumption that the absorption Ångström exponent $(\alpha)$ of traffic is 1.04 (obtained from summer experiment when traffic as source is dominant, Fig. 9e) and the $\alpha$ of wood burning is set to be 1.9 at a first instance (Sect. 3.2). The three methods overall compare with each other very well, apart from a discrepancy between the SP2/BC-AMS-PMF and Aethalometer method occurred from 31 January to 2 February and 8 February when the air mass was easterly and mostly influenced by SF sources. The top panel in Fig. 10 shows the number fraction of $\mathrm{BC}_{\mathrm{sf}}$ as attributed exclusively by the SP2 method. The BC from solid fuel burning contributed much more significantly in terms of mass than number because of the larger $\mathrm{BC}_{\text {sf }}$ core size. Also note that the $\mathrm{BC}_{\text {tr }}$ number fraction will be underestimated because of the lower cut off of the SP2 measurement, thus the true $\mathrm{BC}_{\mathrm{sf}}$ number fraction will be lower.
A statistical comparison among the $\mathrm{BC}$ mass attribution techniques is shown in Fig. 11, and the results are summarised in Table 3. The BC-AMS-PMF method correlates tightly with the SP2 method and is almost on the $1: 1$ line (slope $=1.05, r^{2}=0.80$ ) for the entire experimental period. The Aethalometer attribution at $470-950 \mathrm{~nm}$ correlated well with at $370-880 \mathrm{~nm}$; however, the attribution at 370 $880 \mathrm{~nm}$ was associated with larger variations during $\mathrm{W}$ air masses when aerosol concentrations were lower. For E and SE air masses, compared to the BC-AMS-PMF method, the Aethalometer method exhibited a tighter correlation with the SP2 method ( $r^{2}=0.83$ and 0.70 , respectively) and a slope closer to 1 for $\mathrm{W}$ air masses.

The retrieved $\mathrm{BC}_{\mathrm{tr}}$ and $\mathrm{BC}_{\mathrm{sf}}$ were further examined by comparing with the trace gas species in Table 4. Consistent with the study by Herich et al. (2011), strong correlations was observed for $\mathrm{BC}_{\text {tr }}$ vs. $\mathrm{NO}_{\mathrm{x}}$, and $\mathrm{BC}_{\mathrm{sf}}$ vs. $\mathrm{SFOA}_{\text {total }}, \mathrm{K}$ and levoglucosan. The $\mathrm{BC}_{\mathrm{tr}}$ as attributed by both the SP2 and Aethalometer methods correlates well with $\mathrm{NO}_{\mathrm{x}}$. A bi-linear correlation between $\mathrm{BC}$ and $\mathrm{NO}_{\mathrm{x}}$ is also tested, i.e. $\left(\mathrm{NO}_{\mathrm{x}}\right)=$ $a\left(\mathrm{BC}_{\mathrm{tr}}\right)+b\left(\mathrm{BC}_{\mathrm{sf}}\right)+c$, which will yield a negative value of $b$, the $\mathrm{BC}_{\mathrm{sf}}$ is thus considered to contribute the $\mathrm{NO}_{\mathrm{x}}$ insignificantly during the experiment. Corresponding with the higher $\mathrm{BC}_{\mathrm{sf}}$ mass fraction from the $\mathrm{SP} 2$, the $\mathrm{BC}_{\mathrm{tr}} / \mathrm{NO}_{\mathrm{x}}$ mass ratio is only slightly lower for the SP2 method compared to the Aethalometer method. It is noted for the period of $\mathrm{E}$ air mass, when the discrepancy occurred, the SP2 attributed $\mathrm{BC}_{\text {tr }}$ yielded a higher correlation with $\mathrm{NO}_{\mathrm{x}}\left(r^{2}=0.87\right)$ compared to the Aethalometer method $\left(r^{2}=0.70\right)$. The SP2 attributed $\mathrm{BC}_{\mathrm{sf}}$ correlated better with $\mathrm{SFOA}_{\text {total }}$ because the SP2 method agrees well with the BC-AMS-PMF method. The levoglucosan concentration correlated significantly better with the Aethalometer attributed $\mathrm{BC}_{\mathrm{sf}}\left(r^{2}=0.85\right)$ for the entire period; however, the correlation was weaker with the $\mathrm{SP} 2$ attributed $\mathrm{BC}_{\mathrm{sf}}\left(r^{2}=0.62\right)$ again due to the influence of $\mathrm{E}$ air masses.

The only considerable discrepancy between the methods occurred during E air masses - the Aethalometer method (or levoglucosan concentration) is a factor of approximately 1.7 lower than the SP2 method (or BC-AMS-PMF method). The reason for this is that the Aethalometer attribution relies on the assumed absorption Ångström exponent $(\alpha)$; however, when the site was largely influenced by SF, although the ambient exhibited a higher SFOA/HOA (Fig. 8g) and larger $\mathrm{BC}$ core size (Fig. 8c), the measured $\alpha$ was not correspondingly higher (Fig. 8h). The $\alpha$ of wood burning is highly variable and will change significantly even during the course of a wood fire and also depends strongly on the burning conditions and used wood types as well as the ageing of the biomass smoke (Saleh et al., 2013); therefore, it is possible that this apparent discrepancy reflects a change in $\alpha$.

Another possible source of disagreement is the role of coal burning. This is also used for domestic space heating; however, it has a different emissions profile. The Aethalometer and levoglucosan methods are based around knowledge of 


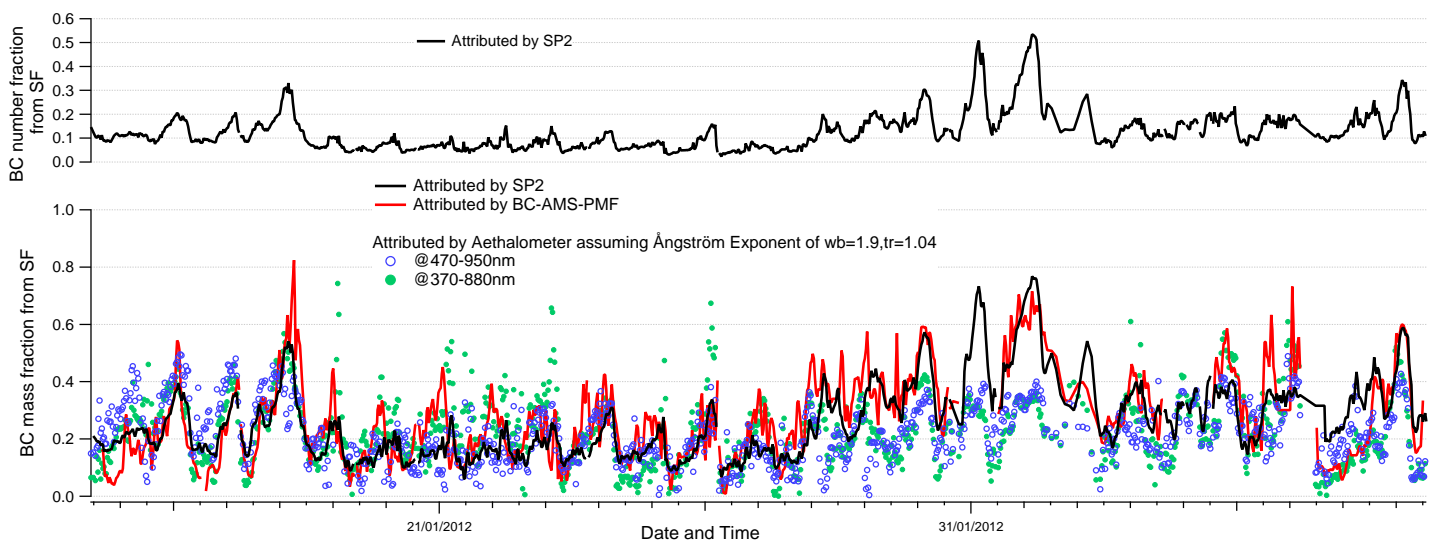

Figure 10. Intercomparisons among different techniques of BC source attribution. The above panel shows the number fraction of BC from a solid fuel burning source which can only be obtained from SP2 attribution.

Table 3. A summary of the correlations among different BC mass attribution techniques: the number is the slope of the linear regression and in brackets is $r^{2} . N$ denotes the data points used for linear regression; ${ }^{*}$ denotes a linear regression constrained to an intercept of zero.

\begin{tabular}{lcccc}
\hline & $\begin{array}{c}\text { BC-AMS-PMF method } \\
\text { /SP2 method* }\end{array}$ & $\begin{array}{c}\text { Aeth method at 470-950 } \mathrm{nm} \\
\text { /SP2 method* } \\
\text { /SP2 method is optimised }\end{array}$ & $\begin{array}{c}\alpha_{b b} \text { when } \\
\text { Aeth method at 470-950 nm }\end{array}$ & $\begin{array}{c}\text { Aeth method at 370-880 } \mathrm{nm} \\
\text { /SP2 method* }\end{array}$ \\
\hline Westerly $(N=441)$ & $1.26(0.53)$ & $0.94(0.46)$ & $1.86 \pm 0.37$ & $\begin{array}{c}\alpha_{b b} \text { when } \\
\text { Aeth method at 370-880 } \mathrm{nm} \\
\text { /SP2 method is optimised }\end{array}$ \\
Easterly $(N=325)$ & $1.04(0.79)$ & $0.58(0.83)$ & $1.58 \pm 0.19$ & $1.21(0.33)$ \\
Southeasterly $(N=407)$ & $1.02(0.41)$ & $0.97(0.70)$ & $1.83 \pm 0.31$ & $0.60(0.58)$ \\
Overall $(N=1173)$ & $1.05(0.80)$ & $0.74(0.53)$ & & $0.96(0.43)$ \\
\hline
\end{tabular}
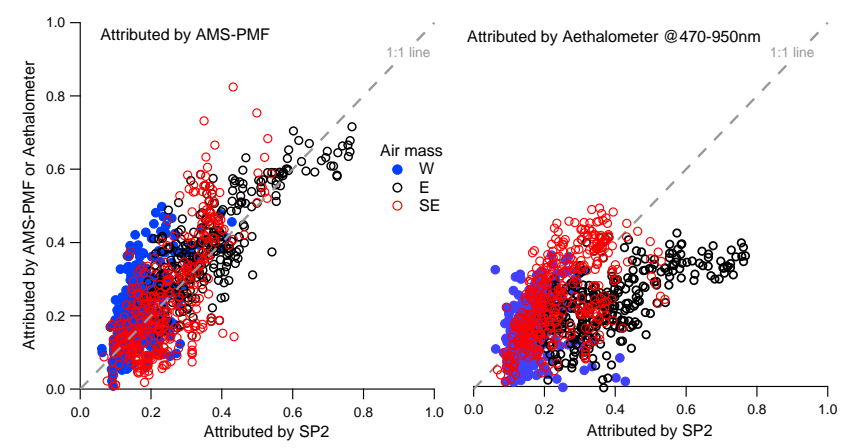

Figure 11. Comparisons between BC-AMS-PMF and Aethalometer $\left(\lambda_{470-950 \mathrm{~nm}}\right)$ attributed $\mathrm{BC}_{\mathrm{sf}}$ mass fraction and the SP2 attribution for different air masses.

wood burning sources, whereas the SP2 and AMS methods are more empirical in nature, so may include contributions from coal burning. Indeed, Yin et al. (2014) found evidence for this in Chemical Mass Balance (CMB) modelling of filter samples analysed using GC-MS and also found that the best correlation with the AMS SFOA factor was achieved with a summation of the wood and coal burning estimates.

Normalising the attributed $\mathrm{BC}_{\mathrm{sf}}$ from the Aethalometer and SP2 methods, an "optimised" $\alpha$ for the solid fuel burning source can be retrieved, as summarised in the right hand column of Table 3. The retrieved $\alpha$ for solid fuel burning for W and SE air masses falls exactly within the range (1.8-
1.9) as suggested by Sandradewi et al. (2008); however, the value of $\alpha$ for the $\mathrm{E}$ air mass is lower (1.60). The $\alpha_{\mathrm{wb}}=1.60$ falls well within the reported $\alpha$ for the fresh wood burning source (Saleh et al., 2013). The E air masses are therefore likely to have brought pollutants from some additional sources which contain significant fractions of aerosols with lower $\alpha_{\mathrm{wb}}$. These sources correspond with a lower content of levoglucosan as observed in this study, which may be explained by the possible coal burning contribution, as the coal burning emissions contain a lesser fraction of levoglucosan (Zhang et al., 2008); however, the coal sources cannot be clearly discriminated by the AMS-PMF analysis in this study.

Another hypothesis is that $\alpha$ may have undergone modification during atmospheric transport and ageing/processes, because levoglucosan is chemically unstable (Hoffmann et al., 2010) and if the chromophores in brown carbon are nitrated aromatics (Mohr et al., 2013), which are also chemically unstable, then both the levoglucosan and brown carbon concentrations will diminish as a result. However, the ageing process has been observed to enhance the short wavelength absorption of secondary organic aerosol hereby increase $\alpha$ (Saleh et al., 2013), the lower $\alpha$ from $\mathrm{E}$ air masses thus likely results from additional sources.

This analysis does not completely exclude the possibility that the SP2 method may have overestimated the $\mathrm{BC}_{\mathrm{sf}}$ by accounting for a fraction of thickly coated $\mathrm{BC}_{\mathrm{tr}}$ although this 
Table 4. The correlations between $\mathrm{BC}_{\mathrm{tr}}$ vs. $\mathrm{NO}_{\mathrm{x}}$, and $\mathrm{BC}_{\mathrm{sf}}$ vs. $\mathrm{SFOA}_{\text {total }}$, potassium and levoglucosan. The $\mathrm{BC}_{\mathrm{tr}}$ and $\mathrm{BC}_{\mathrm{sf}}$ attributed by the SP2 and Aethalometer method are shown. Daily averaged potassium and levoglucosan are used, with a total of days' worth of data used for the linear regression. ${ }^{*}$ Denotes a linear regression constrained to an intercept of zero.

\begin{tabular}{|c|c|c|c|c|}
\hline & $\begin{array}{c}\text { SP2 attributed } \mathrm{BC}_{\mathrm{tr}} / \mathrm{NO}_{\mathrm{x}} \\
\mu \mathrm{g} \mathrm{m}^{-3} \mathrm{ppm}^{-1}\end{array}$ & $\begin{array}{l}\text { Aeth attributed } \mathrm{BC}_{\mathrm{tr}} / \mathrm{NO}_{\mathrm{x}} \\
\qquad \mu \mathrm{g} \mathrm{m}^{-3} \mathrm{ppm}^{-1}\end{array}$ & $\begin{array}{c}\mathrm{SP} 2 \text { attributed } \\
\mathrm{BC}_{\mathrm{sf}} / \mathrm{SFOA}_{\text {total }}^{*}\end{array}$ & $\begin{array}{l}\text { Aeth attributed } \\
\mathrm{BC}_{\mathrm{sf}} / \mathrm{SFOA}_{\text {total }}^{*}\end{array}$ \\
\hline Westerly $(N=441)$ & $27.8 \pm 0.33(0.94)$ & $28.1 \pm 0.40(0.93)$ & $0.13 \pm 0.003(0.83)$ & $0.12 \pm 0.004(0.68)$ \\
\hline Easterly $(N=325)$ & $21.1 \pm 0.47(0.87)$ & $22.5 \pm 0.84(0.70)$ & $0.20 \pm 0.004(0.75)$ & $0.11 \pm 0.002(0.69)$ \\
\hline Southeasterly $(N=407)$ & $17.8 \pm 0.27(0.92)$ & $17.9 \pm 0.32(0.89)$ & $0.11 \pm 0.003(0.85)$ & $0.11 \pm 0.003(0.79)$ \\
\hline \multirow{4}{*}{ Overall $(N=27)$} & $\mathrm{SP} 2$ attributed $\mathrm{BC}_{\mathrm{sf}} / \mathrm{K}$ & Aeth attributed $\mathrm{BC}_{\mathrm{sf}} / \mathrm{K}$ & $\begin{array}{c}\mathrm{SP} 2 \text { attributed } \mathrm{BC}_{\mathrm{sf}} / \\
\text { levoglucosan }\end{array}$ & $\begin{array}{c}\text { Aeth attributed } \mathrm{BCs}_{\mathrm{f}} / \\
\text { levoglucosan }\end{array}$ \\
\hline & $4.13 \pm 0.57(0.70)$ & $3.26 \pm 0.33(0.81)$ & $5.52 \pm 0.91(0.62)$ & $4.75 \pm 0.41(0.85)$ \\
\hline & Offset & Offset & Offset & Offset \\
\hline & $-0.01 \pm 0.06$ & $-0.01 \pm 0.032$ & $-0.08 \pm 0.07$ & $-0.10 \pm 0.03$ \\
\hline
\end{tabular}

effect is deemed to be low during wintertime (Sect. 3.4), i.e. some fraction of aged $\mathrm{BC}_{\text {tr }}$ may have been transported and externally imposed on the more local traffic sources at the site. Another bias may result from the assumed equal mass absorption cross sections $\left(\mathrm{MAC}=\frac{b_{\text {abs }}}{\text { Mass }}\right)$ between the $\mathrm{BC}_{\mathrm{tr}}$ and $\mathrm{BC}_{\mathrm{sf}}$ when calculating the $\mathrm{BC}_{\mathrm{sf}}$ mass fraction, using the $\frac{b_{\mathrm{abs}, \mathrm{wb}, 950 \mathrm{~nm}}}{b_{\mathrm{abs}, \text { total }, 950 \mathrm{~nm}}}$ ratio (Eq. 5). If the $\mathrm{BC}_{\mathrm{sf}}$ has a lower MAC than $\mathrm{BC}_{\mathrm{tr}}$, then the estimated mass of $\mathrm{BC}_{\mathrm{sf}}\left(\right.$ Mass $\left.=\frac{b_{\mathrm{abs}}}{\mathrm{MAC}}\right)$ could be underestimated.

\section{Conclusions}

Carbonaceous aerosols in a London urban site were characterised during the ClearfLo project during both winter and summer seasons in 2012. The traffic-related BC particles exhibited an almost invariant $\mathrm{BC}$ core size $\left(D_{\mathrm{c}}\right)$ distribution and very thin coating thickness throughout the detectable range of $D_{\mathrm{c}}$. However, the size distribution of $D_{\mathrm{c}}$ and BC coating thickness varied significantly in winter due to the influence of additional non-traffic sources, i.e. solid fuel/biofuel burning sources (SF) associated with residential space heating. A novel methodology was developed to attribute the $\mathrm{BC}$ number concentrations and mass abundances from traffic $\left(\mathrm{BC}_{\mathrm{tr}}\right)$ and from $\mathrm{SF}\left(\mathrm{BC}_{\mathrm{sf}}\right)$, by using a 2-D histogram "fingerprint" of the particle optical properties as a function of $\mathrm{BC}$ core size, as measured by the SP2. The $\mathrm{BC}_{\mathrm{tr}}$ and $\mathrm{BC}_{\mathrm{sf}}$ showed clearly different $D_{\mathrm{c}}$ distributions and coating thicknesses. Compared to traffic sources, SF sources introduce $\mathrm{BC}$ particles with larger $\mathrm{rBC}$ cores, and the thicker coatings associated with these result in larger size distributions, particularly during easterly air masses, resulting in a $D_{\mathrm{c}}$ size mode which peaks at $\sim 167 \mathrm{~nm}$ increasing to particle size $\sim 360 \mathrm{~nm}$. These larger BC particles, with thicker coatings, are more likely to exhibit stronger hygroscopicity (Liu et al., 2013) and to be scavenged by wet deposition (Moteki et al., 2012). The larger SF absorbing particles will also have greater potential to enhance the semi-direct effect (Koch and
Del Genio, 2010) through interaction with cloud processes. An increased fraction of non-BC particles (particles that not contain a BC core) was also seen when air masses were influenced by SF sources, which means compared to the BC mass, an even higher fraction of particulate matter, i.e. the organic matter, was introduced by SF sources.

The SP2 BC mass attribution agrees well with the BCAMS-PMF multiple linear regression and the Aethalometer attribution for the entire experiment; only apart from when easterly air masses the $\mathrm{BC}_{\mathrm{sf}}$ attributed by the Aethalometer method was lower compared to the SP2 or BC-AMS-PMF methods, but the Aethalometer method correlated better with the levoglucosan concentration. The additional sources with lower absorption Ångström exponent $(\alpha)$ and lower content of levoglucosan are likely to contribute the pollutants transported from easterly air masses, such as the possible coal burning or other uncertain non-traffic sources; these additional sources may in turn lead to an overestimation of the wood burning sources by the SP2 or BC-AMS-PMF method. More work is needed to further investigate these complex non-traffic sources and to obtain appropriate $\alpha$ values for different solid fuel/biofuel sources is essential to assure reliable Aethalometer model outputs. The BC source apportionment using the SP2 measurement would have the potential of wider applications for the prospective projects. 


\section{Appendix A:}

Table A1. Symbols and abbreviations

\begin{tabular}{ll}
\hline Symbols/abbreviations & Meaning \\
\hline $\mathrm{AMS}$ & Aerosol mass spectrometer \\
$\mathrm{BC}$ & Black carbon \\
$\mathrm{BC}_{\mathrm{tr}}$ & Black carbon from traffic sources \\
$\mathrm{BC}_{\mathrm{sf}}$ & Black carbon from solid fuel burning sources \\
$D_{\mathrm{c}}$ & The black carbon core diameter \\
$D_{\mathrm{p}}$ & The entire particle diameter \\
$E_{\mathrm{S}}$ & The enhancement of scattering \\
$E_{\mathrm{s}-\mathrm{thre}}$ & The threshold scattering enhancement \\
$\mathrm{HOA}$ & Hydrocarbon-like organic aerosol \\
$m$ & Refractive index \\
$\alpha$ & The absorption Ångström exponent \\
$\sigma_{\mathrm{g}}$ & Geometric standard deviation \\
$\mathrm{PMF}$ & Positive matrix factorisation \\
$\mathrm{SP} 2$ & Single-particle soot photometer \\
$\mathrm{SF}$ & Solid fuel burning \\
$\mathrm{SFOA}$ & Solid fuel burning organic aerosol \\
$\mathrm{TD}$ & Thermodenuder \\
\hline
\end{tabular}


Appendix B: The Leading Edge Only (LEO) fitting on the scattering properties of light-absorbing particles from SP2

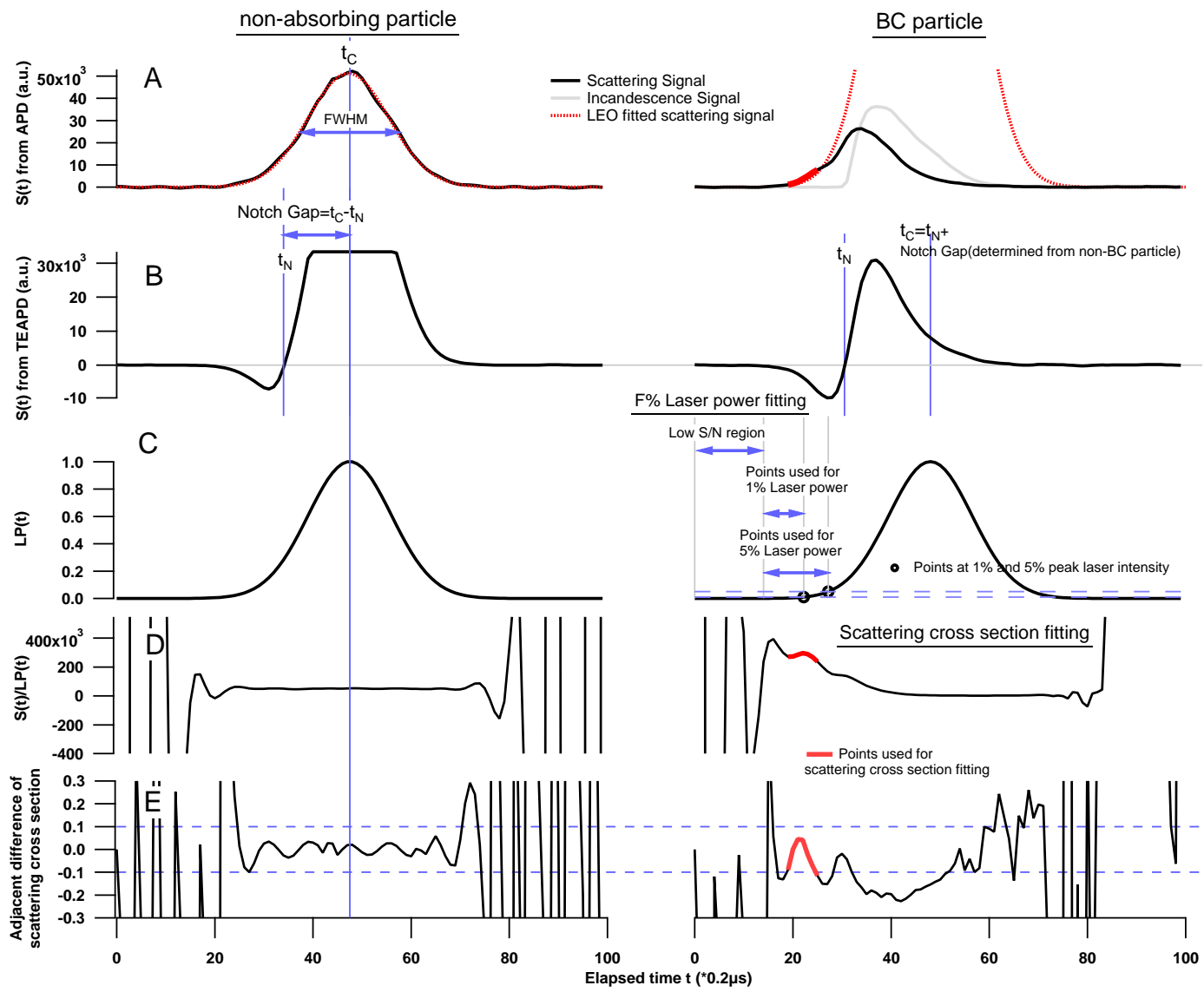

Figure B1. The methodology of leading edge only (LEO) Gaussian fitting. The left panel is a typical example of a single particle event for a non-absorbing particle and the right panel is for an absorbing BC particle. (a) The black line is the measured raw scattering signal $S(t)$ from APD as a function of elapsed time $t$, the $t_{\mathrm{C}}$ is when the peak $S(t)$ occurs at the laser beam centre, the red dot line is the LEO fitted signal, with the grey line on the right panel showing the incandescence signal of the BC particle; (b) the two-element APD (TEAPD) signal used to determine the notch position $t_{\mathrm{N}}$ (the zero-crossing point) and the notch gap $t_{\mathrm{C}}-t_{\mathrm{N}}$; (c) the laser profile $\operatorname{LP}(t)$ as determined by the $\sigma$ and $t_{\mathrm{C}}$, with the blue double-end arrows showing the data points used for the "F\% laser power" fitting method, the data points up to 1 and $5 \%$ peak laser intensity are shown; (d) the relative scattering cross section $\sigma_{\mathrm{S}}(t)=S(t) / \mathrm{LP}(t)$; (e) the adjacent difference of $\sigma_{\mathrm{s}}(t)$ calculated as $\left(\sigma_{\mathrm{S}}(t)-\sigma_{\mathrm{S}}(t-1)\right) / \sigma_{\mathrm{S}}(t)$. The thick red lines on panel (a), (d) and (e) show the data points used for scattering cross section LEO fitting. 


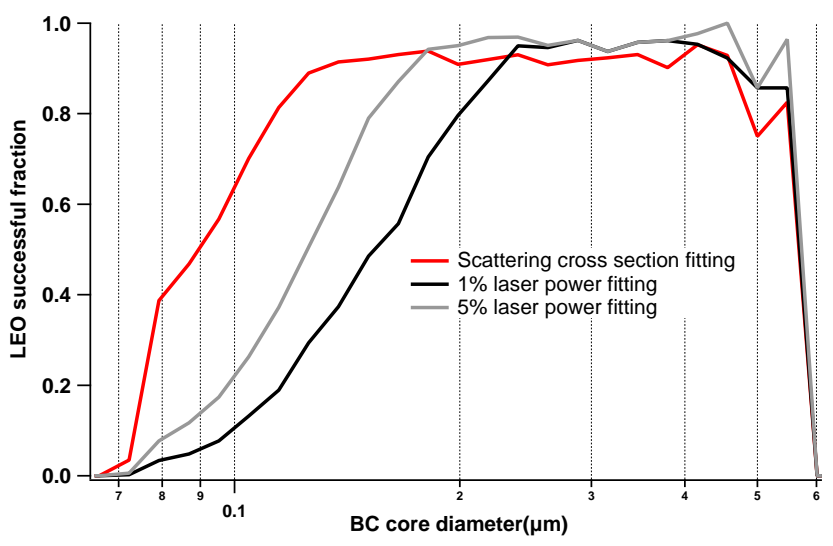

Figure B2. The LEO successful fraction as a function of BC core diameter for different LEO fitting methods.

$S(t)=A e^{-\frac{\left(t-t_{\mathrm{c}}\right)^{2}}{2 \sigma^{2}}}$

The scattering signal of a particle passing through the SP2 laser beam is proportional to the incident laser intensity. Given the Gaussian profile of the laser intensity, the scattering signal $(S)$ at a given elapsed time $(t)$ can be described by a Gaussian function, as Eq. (B1) expresses. The $A$ is the peak amplitude of the scattering signal, $t_{\mathrm{C}}$ is the elapsed time when the particle reaches the laser beam centre and $S(t)$ reaches the peak intensity $A$.

As Fig. B1a shows, the $S(t)$ of a non-absorbing particle will exhibit the ideal Gaussian shape; however, the $S(t)$ of an absorbing particle such as a BC-containing particle will be distorted during its transit through the laser beam because of the mass loss of a BC particle by laser heating (Gao et al., 2007). According to Eq. (A1) in the Appendix, the $S(t)$ is directly measured, and the $A$ can be obtained as long as the $t_{\mathrm{C}}$ and $\sigma$ are known as priori, hereby the $S(t)$ of a BC particle can be reconstructed. To determine the $t_{C}$ when the peak laser intensity necessarily occurs, the notch position $t_{\mathrm{N}}$ is introduced which is the zero-crossing from the two-element-APD detector (TEAPD), as the left blue line of Fig. B1b shows. The notch position relative to the laser beam centre $\left(t_{\mathrm{N}}-t_{\mathrm{C}}\right)$ should be constant for all particles because of the unchanged position of the notch on the TEAPD. The $t_{\mathrm{N}}$ and $t_{\mathrm{C}}$ can both be obtained for non-absorbing particles through direct measurements; however, only $t_{\mathrm{N}}$ can be obtained for BC. In practice, the $t_{\mathrm{N}}-t_{\mathrm{C}}$ is determined in real time by examining the mode value of the previous non-absorbing particles, i.e. the last 200 non-absorbing particles, which is then added onto the $t_{\mathrm{N}}$ of $\mathrm{BC}$ to determine the $t_{\mathrm{C}}$ of a BC particle. The $\sigma$ (calculated by $\mathrm{FWHM}=2 \sqrt{2 \ln 2} \sigma$ ) is also obtained by the previous 200 non-absorbing particles. The relative laser profile $\operatorname{LP}(t)$ (Fig. B1c) which is the Gaussian profile with $A=1$ can then be determined if the $t_{\mathrm{C}}$ and $\sigma$ are fixed.
The next question is how much leading edge only (LEO) fraction of $S(t)$ before the onset of volatilisation can be used to reconstruct the $S(t)$ of a BC particle. Two approaches are tested: the first one is referred as the F\% laser power fitting (Taylor et al., 2014), which is according to the $\operatorname{LP}(t)$, to use the data points ranging from the $t_{0}-$ when the $S(t)$ starts to be above the threshold $S / N$ ratio until the $t_{\mathrm{F}}$ when the $S\left(t_{\mathrm{F}}\right)$ corresponds to a fraction of peak laser intensity, as Fig. B1d shows. The $S(t)\left(t_{0}, t_{\mathrm{F}}\right)$ is then used to be extrapolated using the predetermined $t_{\mathrm{C}}$ and $\sigma$. The 1 and $5 \%$ peak laser intensity are tested in this study. The other approach to determine the LEO range is comparing the measured $S(t)$ with the laser profile $\mathrm{LP}(t)$ to examine the variation of the relative scattering cross section $\sigma_{\mathrm{s}}(t)=S(t) / \mathrm{LP}(t)$, referred to as the scattering cross section fitting. For a non-absorbing particle which is not affected by the laser heating, the $\sigma_{\mathrm{s}}(t)$ should be constant or stable, and this is validated by the $\sigma_{\mathrm{s}}(t)$ of the non-absorbing particle (left panel of Fig. B1d); whereas for a $\mathrm{BC}$ particle, the $\sigma_{\mathrm{s}}(t)$ will be diminished when the particle is evaporated by the laser heating (Laborde et al., 2012a). For a $\mathrm{BC}$ particle, the $\mathrm{LEO}$ range is determined by the stable range of $\sigma_{\mathrm{s}}(t)$, i.e. determined by the adjacent $\%$ difference calculated as $\left(\sigma_{\mathrm{s}}(t)-\sigma_{\mathrm{s}}(t-1)\right) / \sigma_{\mathrm{s}}(t)$. In this study, the $\sigma_{\mathrm{s}}(t)$ is deemed to be stable when $\left|\left(\sigma_{\mathrm{s}}(t)-\sigma_{\mathrm{s}}(t-1)\right) / \sigma_{\mathrm{s}}(t)\right|<10 \%$, as the red lines show. The scattering signal is then reconstructed using the stable $\sigma_{\mathrm{s}}(t)$ range and the predetermined $t_{\mathrm{C}}$ and $\sigma$.

The 1 and $5 \%$ laser power show great correlations with the scattering cross section fitting, with the $1 \%$ laser power fitting obtaining a closer correlation (Slope $=0.99, r^{2}=0.95$; $N=10^{5}$ ) than $5 \%$ laser power fitting (Slope $=0.95$, $\left.r^{2}=0.97 ; N=10^{5}\right)$. However, as Fig. A2 shows, the scattering cross section fitting has significantly increased the successful fraction of LEO fitting especially at the BC core diameter $\left(D_{\mathrm{c}}\right)$ range $\sim 100-200 \mathrm{~nm}$, because the lower $S / N$ ratio for the first few points of the F\% laser power fitting could reduce the quality of the LEO fitting. Given the $D_{\mathrm{c}} \sim 100-200 \mathrm{~nm}$ is the most interested $D_{\mathrm{c}}$ range in this study where the most BC mass loadings are populated, the scattering cross section fitting method is used for this data set. 


\section{Data availability}

Processed data is available through the ClearfLo project archive at the British Atmospheric Data Centre (http://badc. nerc.ac.uk/browse/badc/clearflo). Raw data is archived at the University of Manchester and is available on request.

Acknowledgements. This work was supported through the UK Natural Environment Research Council (NERC) through the ClearfLo (grant ref: NE/H003150/1) and MC4 (grant ref: NE/H008136/1) projects and a PhD studentship (D. Young). We would like to thank the Met Office for the use of the NAME dispersion model.

Edited by: W. Birmili

\section{References}

Allan, J. D., Williams, P. I., Morgan, W. T., Martin, C. L., Flynn, M. J., Lee, J., Nemitz, E., Phillips, G. J., Gallagher, M. W., and Coe, H.: Contributions from transport, solid fuel burning and cooking to primary organic aerosols in two UK cities, Atmos. Chem. Phys., 10, 647-668, doi:10.5194/acp-10-647-2010, 2010.

Baumgardner, D., Popovicheva, O., Allan, J., Bernardoni, V., Cao, J., Cavalli, F., Cozic, J., Diapouli, E., Eleftheriadis, K., Genberg, P. J., Gonzalez, C., Gysel, M., John, A., Kirchstetter, T. W., Kuhlbusch, T. A. J., Laborde, M., Lack, D., Müller, T., Niessner, R., Petzold, A., Piazzalunga, A., Putaud, J. P., Schwarz, J., Sheridan, P., Subramanian, R., Swietlicki, E., Valli, G., Vecchi, R., and Viana, M.: Soot reference materials for instrument calibration and intercomparisons: a workshop summary with recommendations, Atmos. Meas. Tech., 5, 1869-1887, doi:10.5194/amt-51869-2012, 2012.

Bohnenstengel, S. I., Belcher, S. E., Aiken, A. C., Allan, J. D., Allen, G., Bacak, A., Bannan, T. J., Barlow, J. F., Beddows, D. C. S., Bloss, W. J., Booth, A. M., Chemel, C., Coceal, O., Di Marco, C. F., Faloon, K. H., Fleming, Z., Furger, M., Gietl, J. K., Graves, R. R., Green, D. C., Grimmond, C. S. B., Halios, C., Hamilton, J. F., Harrison, R. M., Heal, M. R., Heard, D. E., Helfter, C., Herndon, S. C., Holmes, R. E., Hopkins, J. R., Jones, A. M., Kelly, F. J., Kotthaus, S., Langford, B., Lee, J. D., Leigh, R., Lewis, A. C., Lidster, R. T., Lopez-Hilfiker, F., McQuaid, J. B., Mavendra, D. K., Mohr, C., Monks, P. S., Nemitz, E., Ng, N. L., Percival, C. J., Prévôt, A. S. H., Ricketts, H. M. A., Sokhi, R., Stone, D., Thornton, J. A., Tremper, A. H., Valach, A. C., Visser, S., Whalley, L. K., Williams, L. R., Xu, L., Young, D. E., and Zotter, P.: Meteorology, air quality, and health in London: The ClearfLo project. BAMS-D-12-00245, B. Am. Meteorol. Soc., in press, 2014.

Bond, T. C. and Bergstrom, R. W.: Light absorption by carbonaceous particles: An investigative review, Aerosol Sci. Tech., 40, 27-67, 2006.

Bond, T. C., Doherty, S. J., Fahey, D. W., Forster, P. M., Berntsen, T., DeAngelo, B. J., Flanner, M. G., Ghan, S., Kärcher, B., Koch, D., Kinne, S., Kondo, Y., Quinn, P. K., Sarofim, M. C., Schultz, M. G., Schulz, M., Venkataraman, C., Zhang, H., Zhang, S., Bellouin, N., Guttikunda, S. K., Hopke, P. K., Jacobson, M. Z., Kaiser, J. W., Klimont, Z., Lohmann, U., Schwarz, J. P., Shindell, D., Storelvmo, T., Warren, S. G., and Zender,
C. S.: Bounding the role of black carbon in the climate system: A scientific assessment, J. Geophys. Res., 118, 5380-5552, doi:10.1002/jgrd.50171, 2013.

Canagaratna, M. R., Jayne, J. T., Jimenez, J. L., Allan, J. D., Alfarra, M. R., Zhang, Q., Onasch, T. B., Drewnick, F., Coe, H., Middlebrook, A., Delia, A., Williams, L. R., Trimborn, A. M., Northway, M. J., DeCarlo, P. F., Kolb, C. E., Davidovits, P., and Worsnop, D. R.: Chemical and microphysical characterization of ambient aerosols with the aerodyne aerosol mass spectrometer, Mass Spectrom. Rev., 26, 185-222, doi:10.1002/Mas.20115, 2007.

Canonaco, F., Crippa, M., Slowik, J. G., Baltensperger, U., and Prévôt, A. S. H.: SoFi, an IGOR-based interface for the efficient use of the generalized multilinear engine (ME-2) for the source apportionment: ME-2 application to aerosol mass spectrometer data, Atmos. Meas. Tech., 6, 3649-3661, doi:10.5194/amt6-3649-2013, 2013.

Cappa, C. D., Onasch, T. B., Massoli, P., Worsnop, D. R., Bates, T. S., Cross, E. S., Davidovits., P., Hakala, J., Hayden, K. L., Jobson, B. T., Kolesar, K. R., Lack, D. A., Lerner, B. M., Li, S.M., Mellon, D., Nuaaman, I., Olfert, J. S., Petajä, T., Quinn, P. K., Song, C., Subramanian, R., Williams, E. J., and Zaveri, R. A.: Radiative absorption enhancements due to the mixing state of atmospheric black carbon, Science, 337, 1078-1081, 2012.

Caseiro, A., Bauer, H., Schmidl, C., Pio, C. A., and Puxbaum, H.: Wood burning impact on $\mathrm{PM}_{10}$ in three Austrian regions, Atmos. Environ., 43, 2186-2195, 2009.

Charron, A., Degrendele, C., Laongsri, B., and Harrison, R. M.: Receptor modelling of secondary and carbonaceous particulate matter at a southern UK site, Atmos. Chem. Phys., 13, 1879-1894, doi:10.5194/acp-13-1879-2013, 2013.

Chow, J. C., Watson, J. G., Lowenthal, D. H., Chen, L. W. A., Zielinska, B., Mazzoleni, L. R., and Magliano, K. L.: Evaluation of organic markers for chemical mass balance source apportionment at the Fresno Supersite, Atmos. Chem. Phys., 7, 17411754, doi:10.5194/acp-7-1741-2007, 2007.

Collaud Coen, M., Weingartner, E., Apituley, A., Ceburnis, D., Fierz-Schmidhauser, R., Flentje, H., Henzing, J. S., Jennings, S. G., Moerman, M., Petzold, A., Schmid, O., and Baltensperger, U.: Minimizing light absorption measurement artifacts of the Aethalometer: evaluation of five correction algorithms, Atmos. Meas. Tech., 3, 457-474, doi:10.5194/amt-3-457-2010, 2010.

Crippa, M., Canonaco, F., Lanz, V. A., Äijälä, M., Allan, J. D., Carbone, S., Capes, G., Ceburnis, D., Dall'Osto, M., Day, D. A., DeCarlo, P. F., Ehn, M., Eriksson, A., Freney, E., Hildebrandt Ruiz, L., Hillamo, R., Jimenez, J. L., Junninen, H., Kiendler-Scharr, A., Kortelainen, A.-M., Kulmala, M., Laaksonen, A., Mensah, A. A., Mohr, C., Nemitz, E., O'Dowd, C., Ovadnevaite, J., Pandis, S. N., Petäjä, T., Poulain, L., Saarikoski, S., Sellegri, K., Swietlicki, E., Tiitta, P., Worsnop, D. R., Baltensperger, U., and Prévôt, A. S. H.: Organic aerosol components derived from 25 AMS data sets across Europe using a consistent ME-2 based source apportionment approach, Atmos. Chem. Phys., 14, 61596176, doi:10.5194/acp-14-6159-2014, 2014.

Dall'Osto, M., Ovadnevaite, J., Ceburnis, D., Martin, D., Healy, R. M., O’Connor, I. P., Kourtchev, I., Sodeau, J. R., Wenger, J. C., and O'Dowd, C.: Characterization of urban aerosol in Cork city (Ireland) using aerosol mass spectrometry, Atmos. Chem. Phys., 13, 4997-5015, doi:10.5194/acp-13-4997-2013, 2013. 
DeCarlo, P. F., Kimmel, J. R., Trimborn, A., Northway, M. J., Jayne, J. T., Aiken, A. C., Gonin, M., Fuhrer, K., Horvath, T., Docherty, K. S., Worsnop, D. R., and Jimenez, J. L.: Field-deployable, high-resolution, time-of-flight aerosol mass spectrometer, Anal. Chem., 78, 8281-8289, doi:10.1021/ac061249n, 2006.

Favez, O., El Haddad, I., Piot, C., Boréave, A., Abidi, E., Marchand, N., Jaffrezo, J.-L., Besombes, J.-L., Personnaz, M.-B., Sciare, J., Wortham, H., George, C., and D'Anna, B.: Inter-comparison of source apportionment models for the estimation of wood burning aerosols during wintertime in an Alpine city (Grenoble, France), Atmos. Chem. Phys., 10, 5295-5314, doi:10.5194/acp-10-52952010, 2010.

Fleming, Z. L., Monks, P. S., and Manning, A. J.: Review: Untangling the influence of air-mass history in interpreting observed atmospheric composition, Atmos. Res., 104-105, 1-39, 2012.

Gao, R. S., Schwarz, J. P., Kelly, K. K., Fahey, D. W., Watts, L. A., Thompson, T. L., Spackman, J. R., Slowik, J. G., Cross, E. S., Han, J. H., Davidovits, P., Onasch, T. B., and Worsnop, D. R.: A novel method for estimating light-scattering properties of soot aerosols using a modified single-particle soot photometer, Aerosol Sci. Tech., 41, 125-135, 2007.

Gurjar, B. R., Jain, A., Sharma, A., Agarwal, A., Gupta, P., Nagpure, A. S., and Lelieveld, J.: Human health risks in megacities due to air pollution, Atmos. Environ., 44, 4606-4613, 2010.

Harrison, R. M., Beddows, D. C. S., Hu, L., and Yin, J.: Comparison of methods for evaluation of wood smoke and estimation of UK ambient concentrations, Atmos. Chem. Phys., 12, 82718283, doi:10.5194/acp-12-8271-2012, 2012a.

Harrison, R. M., Laxen, D., Moorcroft, S., and Laxen K.: Processes affecting concentrations of fine particulate matter $\left(\mathrm{PM}_{2.5}\right)$ in the UK atmosphere, Atmos. Environ., 46, 115-124, $2012 \mathrm{~b}$.

Harrison, R. M., Beddows, D. C. S., Jones, A. M., Calvo, A., Alves, C., and Pio, C.: An Evaluation of Some Issues Regarding the Use of Aethalometers to Measure Woodsmoke Concentrations, Atmos. Environ., 80, 540-548, 2013.

Healy, R. M., Sciare, J., Poulain, L., Kamili, K., Merkel, M., Müller, T., Wiedensohler, A., Eckhardt, S., Stohl, A., Sarda-Estève, R., McGillicuddy, E., O'Connor, I. P., Sodeau, J. R., and Wenger, J. C.: Sources and mixing state of size-resolved elemental carbon particles in a European megacity: Paris, Atmos. Chem. Phys., 12, 1681-1700, doi:10.5194/acp-12-1681-2012, 2012.

Herich, H., Hueglin, C., and Buchmann, B.: A 2.5 year's source apportionment study of black carbon from wood burning and fossil fuel combustion at urban and rural sites in Switzerland, Atmos. Meas. Tech., 4, 1409-1420, doi:10.5194/amt-4-1409-2011, 2011.

Herich, H., Gianini, M. F. D., Piot, C., Močnik, G., Jaffrezo, J.-L., Besombes, J.-L., Prévôt, A. S. H., and Hueglin, C.: Overview of the impact of wood burning emissions on carbonaceous aerosols and PM in large parts of the Alpine region, Atmos. Environ., 89, 64-75, 2014.

Hoffmann, D., Tilgner, A., Iinuma, Y., and Herrmann, H.: Atmospheric stability of levoglucosan: a detailed laboratory and modeling study, Environ. Sci. Technol., 44, 694-699, doi:10.1021/es902476f, 2010.

Huffman, J. A., Ziemann, P. J., Jayne, J. T., Worsnop, D. R., and Jimenez, J. L.: Development and characterization of a fast-stepping/scanning thermodenuder for chemically-resolved aerosol volatility measurements, Aerosol Sci. Tech., 42, 395407, 2008.

Jansen, K. L., Larson, T. V., Koenig, J. Q., Mar, T. F., Fields, C., Stewart, J., and Lippmann M.: Associations between health effects and particulate matter and black carbon in subjects with respiratory disease, Environ. Health Persp., 113, 1741-1746, 2005.

Jones, A. R., Thomson, D. J., Hort, M., and Devenish, B.: The UK Met Office's next-generation atmospheric dispersion model, NAME III., Air Pollution Modeling and its Application XVII, edited by: Borrego, C. and Norman, A.-L., Springer, USA, 580 589, 2007.

Koch, D. and Del Genio, A. D.: Black carbon semi-direct effects on cloud cover: review and synthesis, Atmos. Chem. Phys., 10, 7685-7696, doi:10.5194/acp-10-7685-2010, 2010.

Kondo, Y., Matsui, H., Moteki, N., Sahu, L., Takegawa, N., Kajino, M., Zhao, Y., Cubison, M. J., Jimenez, J. L., Vay, S., Diskin, G. S., Anderson, B., Wisthaler, A., Mikoviny, T., Fuelberg, H. E., Blake, D. R., Huey, G., Weinheimer, A. J., Knapp, D. J., and Brune, W. H.: Emissions of black carbon, organic, and inorganic aerosols from biomass burning in North America and Asia in 2008, J. Geophys. Res.-Atmos., 116, D08204, doi:10.1029/2010JD015152, 2011.

Laborde, M., Mertes, P., Zieger, P., Dommen, J., Baltensperger, U., and Gysel, M.: Sensitivity of the Single Particle Soot Photometer to different black carbon types, Atmos. Meas. Tech., 5, 10311043, doi:10.5194/amt-5-1031-2012, 2012a.

Laborde, M., Schnaiter, M., Linke, C., Saathoff, H., Naumann, K.H., Möhler, O., Berlenz, S., Wagner, U., Taylor, J. W., Liu, D., Flynn, M., Allan, J. D., Coe, H., Heimerl, K., Dahlkötter, F., Weinzierl, B., Wollny, A. G., Zanatta, M., Cozic, J., Laj, P., Hitzenberger, R., Schwarz, J. P., and Gysel, M.: Single Particle Soot Photometer intercomparison at the AIDA chamber, Atmos. Meas. Tech., 5, 3077-3097, doi:10.5194/amt-5-3077-2012, 2012b.

Laborde, M., Crippa, M., Tritscher, T., Jurányi, Z., Decarlo, P. F., Temime-Roussel, B., Marchand, N., Eckhardt, S., Stohl, A., Baltensperger, U., Prévôt, A. S. H., Weingartner, E., and Gysel, M.: Black carbon physical properties and mixing state in the European megacity Paris, Atmos. Chem. Phys., 13, 5831-5856, doi:10.5194/acp-13-5831-2013, 2013.

Lanz, V. A., Alfarra, M. R., Baltensperger, U., Buchmann, B., Hueglin, C., Szidat, S., Wehrli, M. N., Wacker, L., Weimer, S., Caseiro, A., Puxbaum, H., and Prevot, A. S. H.: Source attribution of submicron organic aerosols during wintertime inversions by advanced factor analysis of aerosol mass spectra, Environ. Sci. Technol., 42, 214-220, 2008.

Lanz, V. A., Prévôt, A. S. H., Alfarra, M. R., Weimer, S., Mohr, C., DeCarlo, P. F., Gianini, M. F. D., Hueglin, C., Schneider, J., Favez, O., D’Anna, B., George, C., and Baltensperger, U.: Characterization of aerosol chemical composition with aerosol mass spectrometry in Central Europe: an overview, Atmos. Chem. Phys., 10, 10453-10471, doi:10.5194/acp-10-10453-2010, 2010.

Lawrence, M. G., Butler, T. M., Steinkamp, J., Gurjar, B. R., and Lelieveld, J.: Regional pollution potentials of megacities and other major population centers, Atmos. Chem. Phys., 7, 39693987, doi:10.5194/acp-7-3969-2007, 2007.

Liu, D., Flynn, M., Gysel, M., Targino, A., Crawford, I., Bower, K., Choularton, T., Jurányi, Z., Steinbacher, M., Hüglin, C., Curtius, J., Kampus, M., Petzold, A., Weingartner, E., Baltensperger, 
U., and Coe, H.: Single particle characterization of black carbon aerosols at a tropospheric alpine site in Switzerland, Atmos. Chem. Phys., 10, 7389-7407, doi:10.5194/acp-10-73892010, 2010.

Liu, D., Allan, J., Corris, B., Flynn, M., Andrews, E., Ogren, J., Beswick, K., Bower, K., Burgess, R., Choularton, T., Dorsey, J., Morgan, W., Williams, P. I., and Coe, H.: Carbonaceous aerosols contributed by traffic and solid fuel burning at a polluted rural site in Northwestern England, Atmos. Chem. Phys., 11, 1603-1619, doi:10.5194/acp-11-1603-2011, 2011.

Liu, D., Allan, J., Whitehead, J., Young, D., Flynn, M., Coe, H., McFiggans, G., Fleming, Z. L., and Bandy, B.: Ambient black carbon particle hygroscopic properties controlled by mixing state and composition, Atmos. Chem. Phys., 13, 2015-2029, doi:10.5194/acp-13-2015-2013, 2013.

Martin, C. L., Allan, J. D., Crosier, J., Choularton, T. W., Coe, H., and Gallagher, M. W.: Seasonal variation of fine particulate composition in the centre of a UK city, Atmos. Environ., 45, 43794389, 2011.

McMeeking, G. R., Hamburger, T., Liu, D., Flynn, M., Morgan, W. T., Northway, M., Highwood, E. J., Krejci, R., Allan, J. D., Minikin, A., and Coe, H.: Black carbon measurements in the boundary layer over western and northern Europe, Atmos. Chem. Phys., 10, 9393-9414, doi:10.5194/acp-10-9393-2010, 2010.

Middlebrook, A. M., Bahreini, R., Jimenez, J. L., and Canagaratna, M. R.: Evaluation of Composition-Dependent Collection Efficiencies for the Aerodyne Aerosol Mass Spectrometer using Field Data, Aerosol Sci. Tech., 46, 258-271, doi:10.1080/02786826.2011.620041, 2012.

Mohr, C., Lopez-Hilfiker, F. D., Zotter, P., Prevot, A. S. H., Xu, L., Ng, N. L., Herndon, S. C., Williams, L. R., Franklin, J. P., Zahniser, M. S., Worsnop, D. R., Knighton, W. B., Aiken, A. C., Gorkowski, K. J., Dubey, M. K., Allan, J. D., and Thornton, J. A.: Contribution of nitrated phenols to wood burning brown carbon light absorption in Delting, United Kingdom during winter time, Environ. Sci. Technol., 47, 6316-6324, 2013.

Mordukhovich, I., Wilker, E. H., Suh, H., Wright, R. O., Sparrow, D., Vokonas, P. S., and Schwartz, J.: Black carbon exposure, oxidative stress genes, and blood pressure in a repeated measures study, Environ. Health Persp., 117, 1767-1772, 2009.

Moteki, N., Kondo, Y., and Nakamura, S.: Method to measure refractive indices of small nonspherical particles: application to black carbon particles, J. Aerosol. Sci., 41, 513-521, 2010.

Moteki, N. and Kondo, Y.: Dependence of Laser-Induced Incandescence on physical properties of black carbon aerosols: measurements and theoretical interpretation, Aerosol Sci. Tech., 44, 663-675, 2010.

Moteki, N., Kondo, Y., Oshima, N., Takegawa, N., Koike, M., Kita, K., Matsui, H., and Kajino, M.: Size dependence of wet removal of black carbon aerosols during transport from the boundary layer to the free troposphere, Geophys. Res. Lett., 39, L13802, doi:10.1029/2012GL052034, 2012.

Paatero, P.: Least squares formulation of robust non-negative factor analysis, Chemometr. Intell. Lab., 37, 23-35, 1997.

Paatero, P.: The multilinear engine - A table-driven, least squares program for solving multilinear problems, including the n-way parallel factor analysis model, J. Comput. Graph. Stat., 8, 854888, 1999.
Petzold, A., Ogren, J. A., Fiebig, M., Laj, P., Li, S.-M., Baltensperger, U., Holzer-Popp, T., Kinne, S., Pappalardo, G., Sugimoto, N., Wehrli, C., Wiedensohler, A., and Zhang, X.-Y.: Recommendations for reporting "black carbon" measurements, Atmos. Chem. Phys., 13, 8365-8379, doi:10.5194/acp-13-83652013, 2013.

Puxbaum, H., Caseiro, A., Sánchez-Ochoa, A., Kasper-Giebl, A., Claeys, M., Gelencsér, A., Legrand, M., Preunkert, S., and Pio, C.: Levoglucosan levels at background sites in Europe for assessing the impact of solid fuel combustion on the aerosol European background, J. Geophys. Res., 112, D23S05, doi:10.1029/2006JD008114, 2007.

Sahu, L. K., Kondo, Y., Moteki, N., Takegawa, N., Zhao, Y., Cubison, M. J., Jimenez, J. L., Vay, S., Diskin, G. S., Wisthaler, A., Mikoviny, T., Huey, L. G., Weinheimer, A. J., and Knapp, D. J.: Emission characteristics of black carbon in anthropogenic and solid fuel burning plumes over California during ARCTAS-CARB 2008, J. Geophys. Res., 117, D16302, doi:10.1029/2011JD017401, 2012.

Saleh, R., Hennigan, C. J., McMeeking, G. R., Chuang, W. K., Robinson, E. S., Coe, H., Donahue, N. M., and Robinson, A. L.: Absorptivity of brown carbon in fresh and photo-chemically aged biomass-burning emissions, Atmos. Chem. Phys., 13, 76837693, doi:10.5194/acp-13-7683-2013, 2013.

Sandradewi, J., Prevot, A. S. H., Szidat, S., Perron, N., Alfarra, M. R., Lanz, V. A., Weingartner, E., and Baltensperger, U.: Using aerosol light absorption measurements for the quantitative determination of wood burning and traffic emission contributions to particulate matter, Environ. Sci. Technol., 42, 3316-3323, 2008.

Schwarz, J. P., Gao, R. S., Spackman, J. R., Watts, L. A., Thomson, D. S., Fahey, D. W., Ryerson, T. B., Peischl, J., Holloway, J. S., Trainer, M., Frost, G. J., Baynard, T., Lack, D. A., de Gouw, J. A., Warneke, C., and Del Negro, L. A.: Measurement of the mixing state, mass, and optical size of individual black carbon particles in urban and solid fuel burning emissions, Geophys. Res. Lett., 35, L13810, doi:10.1029/2008GL033968, 2008.

Sun, Y.-L., Zhang, Q., Schwab, J. J., Demerjian, K. L., Chen, W.N., Bae, M.-S., Hung, H.-M., Hogrefe, O., Frank, B., Rattigan, O. V., and Lin, Y.-C.: Characterization of the sources and processes of organic and inorganic aerosols in New York city with a high-resolution time-of-flight aerosol mass apectrometer, Atmos. Chem. Phys., 11, 1581-1602, doi:10.5194/acp-11-15812011, 2011.

Szidat, S., Prévôt, A. S. H., Sandradewi, J., Alfarra, M. R., Synal, H.-A., Wacker, L., and Baltensperger, U.: Dominant impact of residential wood burning on particulate matter in Alpine valleys during winter, Geophys. Res. Lett., 34, L05820, doi:10.1029/2006GL028325, 2007.

Taylor, J. W., Allan, J. D., Liu, D., Flynn, M., Weber, R., Zhang, X., Lefer, B. L., Grossberg, N., Flynn, J., and Coe, H.: Assessment of the sensitivity of core/shell parameters derived using the singleparticle soot photometer to density and refractive index, Atmos. Meas. Tech. Discuss., 7, 5491-5532, doi:10.5194/amtd-7-54912014, 2014.

Ulbrich, I. M., Canagaratna, M. R., Zhang, Q., Worsnop, D. R., and Jimenez, J. L.: Interpretation of organic components from Positive Matrix Factorization of aerosol mass spectrometric data, Atmos. Chem. Phys., 9, 2891-2918, doi:10.5194/acp-9-2891-2009, 2009. 
Viana, M., Kuhlbusch, T. A. J., Querol, X., Alastuey, A., Harrison, R. M., Hopke, P. K., Winiwarter, W., Vallius, A., Szidat, S., Prevot, A. S. H., Hueglin, C., Bloemen, H., Wahlin, P., Vecchi, R., Miranda, A. I., Kasper-Giebl, A., Maenhaut, W., and Hitzenberger, R.: Source apportionment of particulate matter in Europe: A review of method and results, J. Aerosol Sci., 39, 827-849, 2008.

Wagener, S., Langner, M., Hansen, U., Moriske, H. J., and Endlicher, W. R.: Spatial and seasonal variations of biogenic tracer compounds in ambient $\mathrm{PM}_{10}$ and $\mathrm{PM}_{1}$ samples in Berlin, Germany, Atmos. Environ., 47, 33-42, 2012.

Weingartner, E., Saathoff, H., Schnaiter, M., Streit, N., Bitnar, B., and Baltensperger, U.: Absorption of light by soot particles: determination of the absorption coefficient by means of aethalometers, J. Aerosol Sci., 34, 1445-1463, 2003.

Yin, J., Harrison, R. M., Chen, Q., Rutter, A., and Schauer J. J.: Source apportionment of fine particles at urban background and rural sites in the UK tmosphere, Atmos. Environ., 44, 841-851, 2010.

Yin, J., Cumberland. S. A., Harrison, R. M., Allan, J., Young, D. E., Williams, P. I., and Coe, H.: Receptor modelling of fine particles in southern England using CMB including comparison with AMS-PMF factors, Atmos. Chem. Phys. Discuss., in press, 2014.

Yttri, K. E., Dye, C., Braathen, O.-A., Simpson, D., and Steinnes, E.: Carbonaceous aerosols in Norwegian urban areas, Atmos. Chem. Phys., 9, 2007-2020, doi:10.5194/acp-9-2007-2009, 2009.
Young, D. E., Allan, J. D., Williams, P. I., Green, D. C., Harrison, R. M., Yin, J., Flynn, M. J., Gallagher, M. W., and Coe, H.: Investigating the two-component model of solid fuel organic aerosol in London: processes, PM1 contributions, and seasonality, Atmos. Chem. Phys. Discuss., 14, 20845-20882, doi:10.5194/acpd-1420845-2014, 2014.

Zhang, Q., Alfarra, M. R., Worsnop, D. R., Allan, J. D., Coe, H., Canagaratna, M. R., and Jimenez, J. L.: Deconvolution and quantification of hydrocarbon-like and oxygenated organic aerosols based on aerosol mass spectrometry, Environ. Sci. Technol., 39, 4938-4952, 2005.

Zhang, Y., Schauer, J. J., Zhang, Y., Zeng, L., Wei, Y., Liu, Y., and Shao, M.: Characteristics of Particulate Carbon Emissions from Real-World Chinese Coal Combustion, Environ. Sci. Technol., 42, 5068-5073, 2008.

Zotter, P., Herich, H., El Haddad, I., Zhang, Y. L., Močnik, G., Hueglin, C., Gysel, M., Baltensperger, U., Szidat, S., and Prévôt, A. S. H.: Evaluation of the absorption Angstrom exponents for traffic and wood burning in the Aethalometer based source apportionment using radiocarbon measurements, Atmos. Meas. Tech., in prepration, 2014. 